\title{
The Impact of Corporate Governance and Financial Leverage on the Performance of Local Thai Banks Using Corporate Social Responsibility as a Mediator
}

\author{
Aamir Sarwar' ${ }^{1}$, Mamdouh Abdulaziz Saleh Al-Faryan² (D), Sara Saeed ${ }^{3}$ \\ ${ }^{1}$ Institute of Administrative Sciences (IAS), University of the Punjab, New Campus, Lahore, Pakistan \\ ${ }^{2}$ Department of Accounting and Financial Management, Faculty of Business and Law, University of Portsmouth, \\ UK \& Consultant in Economics and Finance, Riyadh, Saudi Arabia \\ ${ }^{3}$ Institute of Business and Information Technology (IBIT), University of the Punjab, New Campus, Lahore, Pakistan \\ Email: asarwar@gmail.com, Al-Faryan@hotmail.com, Sarasaeed528285@gmail.com
}

How to cite this paper: Sarwar, A., Al-Faryan, M. A. S., \& Saeed, S. (2022). The Impact of Corporate Governance and Financial Leverage on the Performance of Local Thai Banks Using Corporate Social Responsibility as a Mediator. Theoretical Economics Letters, 12, 19-51.

https://doi.org/10.4236/tel.2022.121003

Received: December 2, 2021

Accepted: January 16, 2022

Published: January 19, 2022

Copyright $\odot 2022$ by author(s) and Scientific Research Publishing Inc. This work is licensed under the Creative Commons Attribution International License (CC BY 4.0).

http://creativecommons.org/licenses/by/4.0/

(c) (i) Open Access

\begin{abstract}
The study looks at the impact of Corporate Governance on the financial performance of seven Thai banks for the period from 2009 to 2018, and also focused on the relationship between corporate governance, leverage, financial performance and Corporate Social Responsibility (CSR) as a mediating variable. Corporate governance was observed through seven variables. Financial performance was measured through three ratios. Relationship between Independent Variables and Dependent Variables was verified through CSR as a mediator. Ordinary Least Square and Two Stage Least Square were used to determine the relationship between the variables. Using Hausman test it was found that Random Effect model was the suitable model. Few of our independent variables were having endogeneity so in order to have stable results we used Two Stage Least Square Method instead of ordinary least square. The study also shows the hidden significance of many relationships. Different statistical tools used for data analysis include MS-Excel, SPSS-23.0, STATA-16, Eviews-10 and Smart-PLS 3.0. This study will help the management of Thai banks to work on the different aspects of Corporate Governance and strategize CSR which can result in improvement of the financial performance. The result will also be helpful for the bank management and policy makers. The data of banks was collected from the Annual reports available online. We could not find any similar study on Thai local banks. This may be the first study on local banks and may contribute towards the literature related to the Corporate Governance.
\end{abstract}




\section{Keywords}

Corporate Governance, Corporate Social Responsibility, Leverage, Financial Performance, Endogeneity, Financial Institutions, Ordinary Least Square, Two Stage Least Square

\section{Introduction}

Corporate Social Responsibility (CSR) and Corporate Governance (CG) are playing major roles in sustainable development of developing countries. CG and CSR are used to improve the financial performance of companies. This study combined the two independent variables (CG and Leverage), one dependent variable (Financial Performance) and one (CSR) as mediator. The board of directors' tasks include supporting and monitoring management initiatives, as well as reviewing, incentivizing, awarding, and penalizing managerial performance. Many earlier studies have done their research to find the relationship between CG and performance of the organizations. The basic and foremost purpose of the study was to find out implementation of CG in the financial sector in Thailand and what are the impacts on their financial performance. Moreover, the study also tried to validate the relationship between the Leverage and Financial performance with mediating role of CSR. This study used the mix of corporate governance and leverage and their impact on the financial performance of organizations. Earlier studies mostly linked two variables, whereas, our study combined the two independent variables, one dependent variable and one as mediator. One cannot deny the importance of the role of banking sector in any economy, especially Thailand, one of the emerging markets of Asia. We have just selected the local banks only. Banking regulations are different from other industrial or services sectors such as BASEL Accord, I, II, and III. Banks have their own requirements in different areas like equity, leverage and liquidity management. This study will cover in detail all the links that exist or may exist between the multiple variables. We could not find any such study on banking sector in Thailand which combines three variables, and observes the relationships in detail.

The data of seven Thai banks for the period 2009-2018 was used for the analysis. The findings validated the different results of earlier studies. We used the Hausman Test, which confirmed that the Random Effect model was the suitable model. We also used the Durbin-WU-Hausman test to find the endogeneity in our variables and used the TSLS rather than OLS. This study will contribute to the literature on CG and help management of banks and policymakers. The study also highlighted the hidden significance of many relationships, including the mediator, which can be very helpful for the management of banks and policy makers of Thailand. 
First of all, we will briefly define all the variables and terms that will be used in our study.

Corporate governance is essential because it establishes a set of rules and procedures that regulate how a company works and how all of its stakeholders' interests are aligned. Corporate governance leads to ethical business practices, and ethical business practices lead to financial viability. CSR initiatives lead to positive organizational outcomes such as improved business reputation, customer loyalty, and performance. According to (Carroll, 2016), four-part definition of CSR was originally stated as follows: "Corporate social responsibility encompasses the economic, legal, ethical, and discretionary (philanthropic) expectations that society has of organizations at a given point in time". The academic literature in the 2000s saw relevant contributions to the notion, as indicated by Latapi Agudelo et al. (2019) the institutional and public influence in the implementation of CSR. Corporate social responsibility is beneficial to both your society and your company's image. CSR initiatives have become an important part of the marketing strategy for many companies today. Financial leverage-the amount of stock and debt used to fund a company's assets is referred to as financial leverage. Financial leverage has been shown to have a link with financial performance in several research. A company's return on equity improves at an optimal level of financial leverage because it raises stock volatility. Financial Institution in every country also have to follow the regulations of the central banks of the country, where limits may be set for the equity and debt requirements which may have impact on their financial performance. Financial performance indicators (FPIs a company's financial health and long-term survival depend on its bottom-line profit margin. Financial ratios are divided into four categories: profitability or return on investment, liquidity, leverage and operational efficiency. The ROA figure gives investors an idea of how effective the company is converting the money it invests into net income.

The goal of this study is to see how corporate governance and financial leverage affect operating, market, and financial performance of Thai banks, with corporate social responsibility as a mediating variable. The following are the main goals of the study:

- To study various dimensions of corporate governance that could have been used to measure it.

- To study the correlation between different performance indicators (market, operating, accounting and financial).

- To study the impact of financial leverage on financial performance of local banks of Thailand with a mediating effect of Corporate Social Responsibility.

- To study the impact of Corporate Governance on financial performance of local banks of Thailand with a mediating effect of Corporate Social Responsibility.

Research questions are as follows:

1) What are the factors used to measure corporate governance? 
2) What are the factors used to measure financial, accounting, market and operating performance of the banks listed in Thailand stock exchange?

3) What is the impact of financial leverage and corporate governance on performance of the banks?

4) What is the role of Corporate Social Responsibility as a mediator between Financial Leverage, Corporate Governance as Independent Variables and Financial Performance of local Thai banks listed on Thailand Stock exchange as a dependent variable?

The paper is organized as follows. Section (1) examines the linked literature on corporate governance, corporate social responsibility, leverage, and financial performance measures. Section (2) covers the gap analysis and variables selected for this study and its rationale. Section (3) data analysis and methodology and results/output. Section (4) outlines the Conclusion and discussion of key findings. Section (5) will discuss the limitations and guidelines for future studies. Section (6) finishes the paper.

\section{Literature Review and Hypothesis Development}

The review of literature is divided into three sections. The first section examines the relevant literature on the themes covered in international studies. In addition, available literature has employed diverse sectors to analyse the relationships. The established relationships of individual sectors will be explored in detail. The Second Section sums up the literature, explaining the gaps that will be filled by the present study. Section three explains the conceptual framework and hypotheses of our study. According to Gompers et al. (2003) there is a positive relationship between better governance and firm performance.

Klapper \& Love (2004) used CLSA (Credit Lyonnais Securities Asia) index for governance and find a positive relationship was found between CG and ROA. The degree of ownership shares of institutional investors in a company, level of debt and size of company influence the rate of return on equity (Leng, 2004). Core et al. (2005) found that poor governance is the cause of poor returns.

The study of Chen et al. (2005) found that composition of the board of directors has little impact on firm performance and dividend policy. The study of Javed \& Iqbal (2006) evaluated the performance of companies listed on KSE Pakistan is estimated through use of Tobin $Q$ and found that positive relationship between firm's performance and quality of corporate governance. Black et al. (2006) analyzed correlation between change in the quality of corporate governance and the change in market valuation. Cheung et al. (2007) resolved the issue of measuring corporate governance and developed an instrument to access corporate governance.

Brown \& Caylor (2009) used unique data on ISS governance factors constructed a governance score. Research shows six of the governance factors were positively related with ROA and ROE.

Ertugrul \& Hegde (2009) examined the rating of corporate governance pro- 
vided by three US agencies. Chi (2011) stated that there is negative correlation between the Governance Index and Tobin's Q ratio. According to Braga-Alves \& Shastri (2011) in 2000 Sao Paulo Stock Exchange generated one market segment for courtiers observing good corporate governance.

Corporate governance (CG) and performance has a significant relationship between board size and ROE in Pakistan. Gill \& Obradovich (2012) analyzed the impact of corporate governance to analyze the relationship with financial profitability indicators. According to Shan \& Round (2012) effective CG is crucial for economic development. Setiawan \& Phua (2013) analyzed that firms with strong corporate governance are much more profitable, but that greater profitability is the only one reason behind higher dividend payouts. But the positive relationship between corporate governance. Directors have the duty to check and evaluate management to ensure that they are working in a suitable strategic direction. Along with this they are accountable to shareholders and should inform them that all their activities and decisions made by them are serving the best interest of shareholders (Collier \& Roberts, 2016).

Broad and narrow concepts of corporate governance were analyzed by Nag (2016). Broad corporate governance includes control of companies, role of stock market and role of bank. Narrow corporate governance is about financial regulation, regulations in terms of company law and industrial relations. Buallay et al. (2017) used panel data of 171 listed companies in Saudi stock exchange and finding shows that instead of highest governance practice adopted by firms, still there is insignificant relationship of corporate governance on firm's operational and financial performance. But significant relationships are found between CG variables (ownership and board of directors) and firm performance. Pillai \& Al-Malkawi (2018) used the data set of 349 companies listed in the stock exchange of GCC countries and the results show the significance of relationships between governance variables and firm performance. Upadhyay \& Öztekin (2020) explained that firms whose board is independent in decision making do not show an increase in performance. There are so many issues related to corporate governance. Macey et al. (1995) presented a model that presents upcoming trends in corporate governance.

\subsection{Leverage}

Yoon \& Jang (2005) investigated the relationship between financial leverage, profitability and risk on restaurant businesses. Findings of Jang \& Tang (2009) indicated that leverage has a direct inverted U-shaped relationship with profitability and indirect relationship between leverage and international diversification suggesting that financial strategies are an efficient way of achieving higher profitability than business practices. According to Singapurwoko \& El-Wahid (2011) debt in general has a significant effect on companies' profitability. But debt is not the only reason behind company profitability. González (2013) found the effect of leverage on operating performance of corporations and explored that le- 
verage became the cause of economic distress and decreased operating profit because indirect cost related with financial distress is much more than the profit generated from using debt.

Hong \& Sullivan (2013) provided the empirical evidence on one of the major issues of corporate governance that is relationship between leverage and corporate performance. Higher the access to credit, the higher leverage that would result in high performance. Abdallah \& Hussein (2014) conducted analysis on Saudi industrial companies and found a weak and reverse relationship between leverage and stock value. Further research by Ahmad et al. (2015) found that there is a negative significant relationship between financial leverage and profitability. Ozdagli et al. (2017) stated that firms with high operating and financial leverage face large equity risk premiums. Ramzan et al. (2021) stated high level of leverage is the cause of reduction in financial stability. According to the Zhou et al. (2021) high profitable companies have sufficient funds and are not dependent on external debt. This would probably reduce the threat of bankruptcy and financial crisis for the companies of China (Chinese non-financial listed firms during 2000-2018).

\subsection{Corporate Social Responsibility}

Pang \& Yuan (2019) mentioned that based on their own experience and the necessity for theoretical development, active supporters of corporate social responsibility define the various meanings of corporate social responsibility from several angles. In a nutshell, the basis of CSR theory is that businesses are social entities, with "social people" as one of their distinguishing characteristics. Ethical CSR (means ethical duties and responsibilities) is mandatory for business. Strategic CSR is good for society and business as well. Lantos \& Easton (2001) reviewed the concept of CSR in terms of its four components: economic, legal, ethical and altruistic. As explained by Porter \& Kramer (2002) strategic value of CSR is becoming increasingly recognized because CSR participation can improve stakeholder's participation by reducing business risk. Orlitzky et al. (2003) conducted meta-analysis and explained the positive relationship between corporate social responsibility and corporate financial performance. Corporate social responsibility was highly correlated with accounting-based measures and of corporate financial performance than the market-based measures of corporate financial performance.

Madden et al. (2006) conducted exploratory research on Australian SMEs and found firm size is the most neglected issue but it is found to be the most vital issue that can affect CSR participation. Udayasankar (2008) argued that despite less resource availability, small scale operations and lower visibility, small firms are more likely to participate in CSR initiatives. The relationship between economic conditions and corporate behavior can be affected by many factors including public and private regulation, the presence of independent and non-governmental organizations that monitor corporate behavior, and institutionalized standards regard- 
ing appropriate corporate behavior. Firms with good CSR practice usually bear high rates of interest (Sharfman \& Fernando, 2008).

A study by Margolis \& Walsh (2011) has shown that Firm's financial performance is affected by their engagement in socially responsible corporate behavior, conservatively well-defined, rather than their financial performance. El Ghoul et al. (2011) stated that CSR is associated with lower cost of equity capital investment to improve responsible employee relations, environmental policies and strategies of products will help in reducing cost of equity. In the absence of security, lenders are more concerned about CSR. Lenders are indifferent to CSR while issuing loans to high quality borrowers but for low quality borrowers CSR is important. Goss \& Roberts (2011) described that firms with poor and low environmental and social performance usually pay high cost on their private bank debts.

According to Orlitzky et al. (2011) the strategic view of CSR that states voluntary actions of CSR have positive effect on interest of primary stakeholders and this will boost firm's competitiveness and reputation. Institutional force helps the companies to serve stakeholders in the best way and to behave responsibly that would lead towards higher CSR ranking (Esa \& Ghazali, 2012). Lau et al. (2016) found insignificant relation between board composition and CSR performance.

With CSR, loyal customers can be found and these customers will help in achieving organizational goals of increased value from their participation and good behavior, according to a study by the World Economic Forum (WEF). Over investment theory states that top management used CSR practices to enhance their private gains to social citizen reputation but this could cause decline in their market value. Kim et al. (2017) found that firms following CSR are different from those who are not involved in CSR activities. The impact of CSR on firm value is significant, representing that CSR plays an important role to increase firm's value. Research done by Mc Williams \& Siegel (2018) shows that CSR can enhance various stakeholders' relations. Bianchi et al. (2019) stated that due to uncertainties in the business environment, reputation has become crucial for business success, because flow of asymmetrical information between clients and business makes the ability of clients weak to predict future. Due to major issues of corporate governance like dangerous and hazardous products and services, corruption and political investment in the business sector CSR is gaining more importance (Vogler \& Eisenegger, 2020). According to the study of Ullah et al. (2020) encouraging corporate social responsibility (CSR) has become an essential task in marketing strategy for companies. CSR activities produce an optimistic organizational outcome in the form of corporate reputation, customer loyalty and performance. Bannier et al. (2021) determined Credit rating agencies tend to award comparatively high ratings to firms with good social performance. CSR provides the important non-financial information that credit rating agencies use in their evaluation. 


\subsection{GAP Analysis in Research}

The following are the few recent studies in the area of Corporate Governance and its relations with different variables like corporate social responsibility, leverage and financial performance having different constructs and showing similar and different results among different combinations. Brown \& Caylor (2009) determined that companies with low scores of governances have higher ROE, profits margins and firms' valuation. The study of the Chi (2011) stated that there is negative correlation between the Governance Index with future Tobin's $\mathrm{Q}$ ratio and also stated that G-Index is not authentic for measuring CG based on his results.

Shan \& Round (2012) study emphasized that independent and strict set of checks on management are needed. According to Setiawan \& Phua (2013) strong corporate governance is much more profitable. Pillai \& Al-Malkawi (2018) analyzed the relation of CG with performance and found significance of relationship among governance variables and firm performance. The study of Jang \& Tang (2009) indicated that leverage has a direct inverted U-shaped relationship with profitability and indirect relationship between leverage and international diversification suggesting that financial strategies are an efficient way of achieving higher profitability than business practices.

According to Singapurwoko \& El-Wahid (2011) debt in general has a significant effect on companies' profitability. But there are many other macroeconomic factors that affect the performance of a company. As determined by the study of Hong \& Sullivan (2013) debt financing puts pressure on managers to compel them to perform efficiently and these results in high corporate performance.

The study of Ahmad et al. (2015) statistical test resulted in a negative significant relationship between financial leverage and profitability. Ramzan et al. (2021) stated that high level of leverage is the cause of reduction in financial inclusion and financial stability. The result of the study of Zhou et al. (2021) indicated a negative relationship between quality governance and leverage. Finding also proved that financial leverage has a negative impact on firm financial performance. Margolis \& Walsh (2011) concluded that the firms should focus more on their institutional mechanism instead of social performance to increase their financial performance. Voluntary actions of CSR have a positive effect on the interest of primary stakeholders and this will boost the firm's competitiveness and reputation. Kim et al. (2017) analyzed the relationship between CG and firm value through CSR. According to Yadav et al. (2018) CSR and CG are playing a major role in the sustainable development of developing countries. Vogler \& Eisenegger (2020) concluded that due to major issues of corporate governance like dangerous and hazardous products and services, corruption and political investment in the business sector CG is gaining more importance. As determined by Ullah et al. (2020) encouraging corporate social responsibility (CSR) has become an essential task in marketing strategy for companies. CSR activities produce an 
optimistic organizational outcome in the form of corporate reputation, customer loyalty and performance. Bannier et al. (2021) determined that credit rating agencies tend to award comparatively high ratings to firms with good social performance.

Different studies used different relations between variables. In our study, we tried to have different constructs for different variables and we tried to test different relationships. The study of these factors in the banking sector in an emerging economy distinguishes it from past research. Only a few studies also involved the impact of mediators and control variables. We have used the CSR as a mediator between the CG and Financial Performance (FP). We also used leverage as an independent variable and as a mediator. The empirical analysis makes positive contributions to the corporate governance literature. We will see how and where the results are similar and different from previous results, so that they can provide some guidelines for policy makers. The empirical analysis in this paper makes positive contributions to the corporate governance and CSR literature.

Our study's hypotheses and conceptual framework and are as follows, based on our literature review and research questions:

$\mathrm{H}_{01}$ : Data of Corporate Governance is Normal.

$\mathrm{H}_{02}$ : There is no multicollinearity among the different data Sets.

$\mathrm{H}_{02}$ : There is no heteroscedasticity among the different data sets.

$\mathrm{H}_{04}$ : Random Effect test is the appropriate test-Hausman Test.

$\mathrm{H}_{05}$ : Independent variables are exogeneous-Durban-Wu-Hausman Test.

$\mathrm{H}_{06}$ : There is no mediating effect of M (Mediator: Corporate Social Responsibility) on relationship between " $\mathrm{X}$ " (Independent Variable-Leverage) and " $\mathrm{Y}$ " (Dependent Variable-Financial Performance).

$\mathrm{H}_{07}$ : There is no mediating effect of $\mathrm{M}$ (Mediator: Corporate Social Responsibility-CSR) on relationship between "X" (Independent Variable: Leverage-LEVRG) and "Y" (Dependent Variable: Financial Performance-FP).

$\mathrm{H}_{08}$ : There is no mediating effect of $\mathrm{M}$ (Mediator: Leverage-CSR) on relationship between " $X$ " (Independent Variable: Corporate Governance-CG) and "Y" (Dependent Variable: Financial Performance-FP).

Following is the conceptual framework of our study which was developed after thorough Literature review.

In our study (Figure 1), corporate governance (CG) and leverage (LEVRG) are the independent variables, while financial performance (FP) is the dependent variable, whereas corporate social responsibility (CSR) will be used as a mediator. Where corporate governance variables are: AQ is Audit Quality, BS is Board Size, CDLTY is CEO Duality, IND is Percentage of Independent Directors, INSH is Percentage of Insiders, LISH is Percentage of Large Institutions, and TMSH is Percentage of two major shareholders. While measures of financial performance are: OP is operating profit ratio for operating performance, ROA is Return on Assets and Tobin Q. 


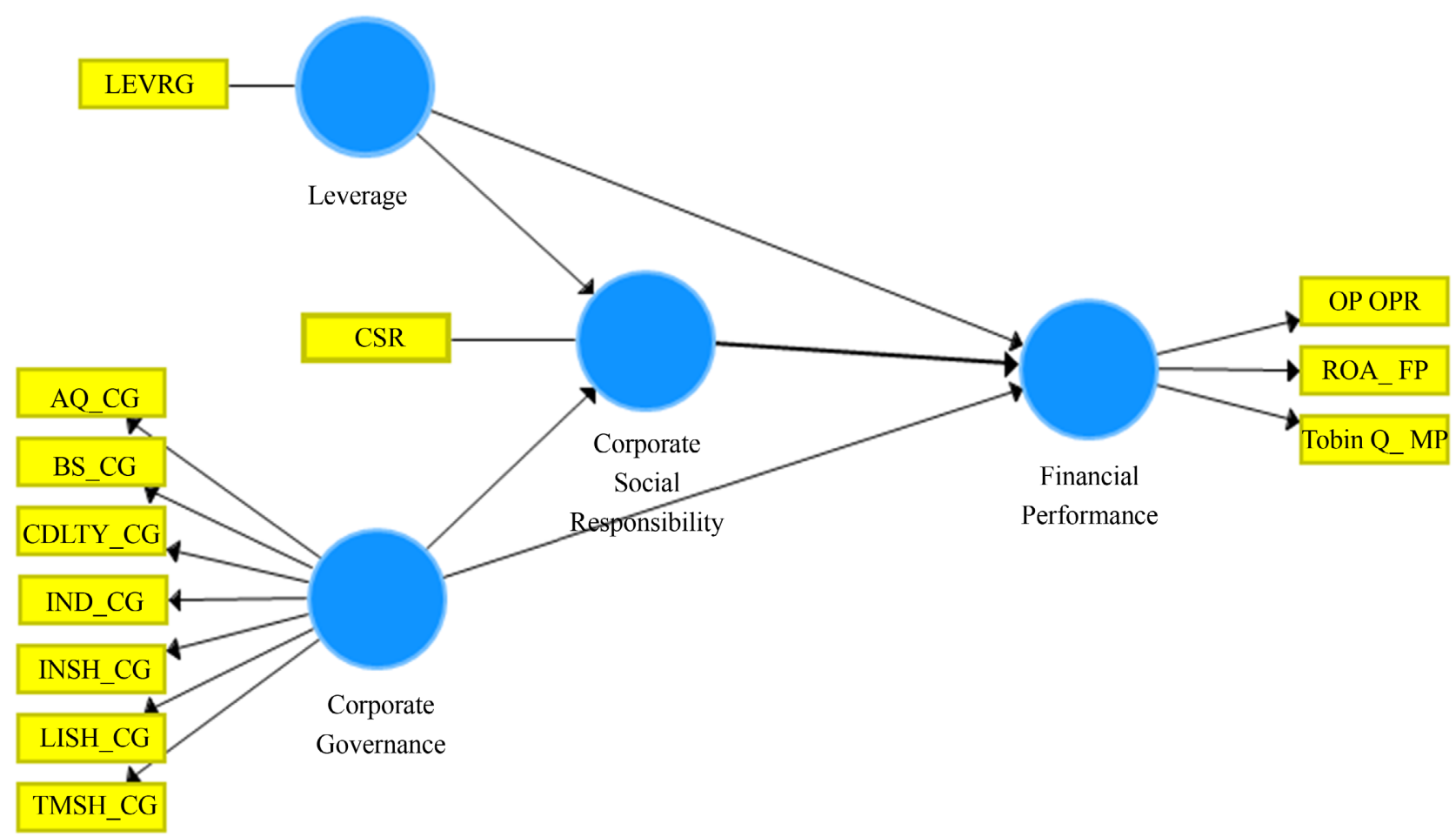

Figure 1. Conceptual framework.

\section{Methodology and Data Analysis}

\subsection{Methodology}

The main purpose of this paper is to examine the impact of certain internal corporate governance mechanisms and financial leverage on financial, operating and market performance (Buallay et al., 2017) of the local banks listed in Thailand stock exchange. In order to assess the relationship between CG, LEV, and $\mathrm{FP}$, the following models are drawn:

$$
\mathrm{FP}=f(\mathrm{CG}+\mathrm{LEV})
$$

where banks financial performance (FP) is a function of corporate governance and Financial Leverage (LEV).

Panel regression model can be written as:

$$
\begin{gathered}
Y=\alpha_{0}+\beta x+e \\
I=1, \cdots, N \text { and } t=1, \cdots, T
\end{gathered}
$$

where " $P$ " is cross-section dimesion $(i=1, \cdots, N), t$ is time dimension $(1,5), Y$ is the dependent variable (FP) for bank $I$ and period $t, x$ is a vector of explanatory variables, $\beta$ is vector of parameters to be estimated and $e$ is the error term. On the basis of research formulated the empirical model for banks $I$ in period $t$ can be written as:

$$
\begin{aligned}
\mathrm{FP} & =\alpha_{0}+\beta_{1} \mathrm{CG}+\beta_{2} \mathrm{LEV}+e \\
\mathrm{CSR} & =\alpha_{0}+\beta_{1} \mathrm{CG}+\beta_{2} \mathrm{LEV}+e
\end{aligned}
$$




$$
\mathrm{CSR}=\alpha_{0}+\beta_{1} \mathrm{FP}+e
$$

Further breaking corporate governance variable and adding mediating variable CSR in equation:

$$
\begin{aligned}
\mathrm{FP}= & \alpha_{0}+\beta_{1} \mathrm{INSH}+\beta_{2} \mathrm{LISH}+\beta_{3} \mathrm{AQ}+\beta_{4} \mathrm{CDLTY}+\beta_{5} \mathrm{TMSH} \\
& +\beta_{6} \mathrm{IND}+\beta_{7} \mathrm{BS}+\beta_{8} \mathrm{CSR}-\beta_{9} \mathrm{LEV}+e
\end{aligned}
$$

\subsubsection{Independent Variables}

There are two independent variables, i.e. Financial Leverage (LEV) and Corporate Governance (CG) Pillai \& Al-Malkawi (2018). Operationalization of CG includes (CDLTY, LISH, INSH, BS, IND, AQ, TMSH) CEO duality, percentage of shares held by large institutions, percentage of shares held by insiders, board size, no of independent directors in board, and presence of big 4 in audit committee and lastly the percentage of two major shareholders. Leverage is a measure of debt ratio Pillai \& Al-Malkawi (2018) and Buallay et al. (2017). This ratio is measured as Total Debt divided by Total Assets.

\subsubsection{Dependent Variables: Bank Financial Performance (FP)}

Dependent variable is the financial performance of the bank. Financial performance is composite of ROA operating profit ratio for operating performance, and Tobin Q (Pillai \& Al-Malkawi, 2018; Buallay et al., 2017). Where bank performance is measured by using both Tobin $\mathrm{Q}$ and ROA suggested by Black et al. (2006) according to them corporate governance is assumed differently by inside and outside investors. Accounting measure is for internal management and Tobin $\mathrm{Q}$ is for outside investors. Bank performance is measured by using both Tobin $\mathrm{Q}$ and ROA as suggested by (Black et al., 2006). For CG research both measures are integrated and used skillfully for ensuring helpful information about the banks and this will help in future to build effective corporate governance policies.

\subsubsection{Mediating Variable}

Corporate Social responsibility is used as a mediating variable between independent variables and dependent variables. Thai Banks have been practicing corporate social responsibility (Pillai \& Al-Malkawi, 2018).

\subsection{Data}

The study consists of seven local banks listed in Thailand sustainability investment securities by the stock exchange of Thailand for a ten-year time period. The relationship between CG and leverage on banks financial performance, operational and market performance is viewed and analyzed from the equilibrium model approach. The study is analyzed on data set of local banks registered/listed in Thailand stock exchange. These banks have adopted good CSR practices and publish sustainability report annually. The banks included in data are following: 
1) Bank of Thailand

2) Bank of Ayudhya

3) Kasikoran Bank

4) Kiantnakin Bank

5) Krungthai Bank

6) TMBT Thanachat Bank

7) Siam Commercial Bank

\section{Results and Discussion}

\subsection{Result}

We test few basic assumptions, which will help us to understand about the different tests to be applied for the study. Normality, multicollinearity, heteroscedasticity tests and correlation matrix are the main tests used in the study. First of all, we will determine the normality of the data using Kolmogorov-Smirnov, test of normality. Results are given below (Tables 1-3):

Table 1. Tests of normality.

\begin{tabular}{ccccccc}
\hline & \multicolumn{3}{c}{ Kolmogorov-Smirnov } & \multicolumn{3}{c}{ Shapiro-Wilk } \\
\cline { 2 - 7 } & Statistic & df & Sig. & Statistic & df & Sig. \\
\hline LEVRG & 0.014 & 69 & $0.200^{*}$ & 0.997 & 69 & 1.000 \\
CSR & 0.080 & 69 & $0.200^{*}$ & 0.985 & 69 & 0.594 \\
Tobin Q & 0.021 & 69 & $0.200^{*}$ & 0.997 & 69 & 1.000 \\
ROA & 0.094 & 70 & $0.200^{*}$ & 0.974 & 70 & 0.151 \\
Operating Profit Ratio & 0.015 & 69 & $0.200^{*}$ & 0.997 & 69 & 1.000 \\
TMSH_CG & 0.044 & 70 & $0.200^{*}$ & 0.994 & 70 & 0.990 \\
LISH_CG & 0.030 & 69 & $0.200^{*}$ & 0.989 & 69 & 0.826
\end{tabular}

Significance at $5 \%$.

Table 2. Multicollinearity between all independent variables (CG and LEVRG).

\begin{tabular}{ccc}
\hline & VIF & $1 /$ VIF \\
\hline INSH-CG & 5.757 & 0.174 \\
LISH-CG & 5.459 & 0.183 \\
TMSH-CG & 5.206 & 0.192 \\
BS-CG & 2.954 & 0.339 \\
LEVRG & 2.43 & 0.412 \\
IND-CG & 1.754 & 0.570 \\
AQ-CG & 1.649 & 0.606 \\
CDLTY-CG & 1.552 & 0.644 \\
Mean VIF & 3.345 &. \\
\hline
\end{tabular}

Significance at $5 \%$. 
Table 3. Heteroskedasticity using white test (LEVRG and CG with Tobin Q).

\begin{tabular}{cccc}
\hline Source & $\mathrm{Chi}^{2}$ & Df & $\boldsymbol{p}$ \\
\hline Heteroskedasticity & 30.580 & 30 & 0.436 \\
Skewness & 11.120 & 8 & 0.195 \\
Kurtosis & 1.080 & 1 & 0.298 \\
Total & 42.780 & 39 & 0.312 \\
\hline
\end{tabular}

Significance at $5 \%$.

$\mathrm{H}_{01}$ : Data of Corporate Governance is Normal.

We can see that our independent variables are normal as value of $p>0.05$, so we accept the null hypothesis.

$\mathrm{H}_{02}$ : There is no multicollinearity among the different data sets.

Multicollinearity is measured through VIF, value of VIF is less than 10, therefore we accept the null hypothesis that there is no multicollinearity.

$\mathrm{H}_{03}$ : There is no heteroscedasticity among the different data sets.

Heteroskedasticity is measured using White test and we can see in Tables 3-5, $p$ values are greater than 0.05 , therefore we accept the null hypothesis, i.e., there is no heteroskedasticity among the different variables.

Significance at $5 \%$, Pearson Correlation is used to find the significant correlation among dependent variables e.g., Tobin $\mathrm{Q}$, operating profit, and ROA. Tobin $\mathrm{Q}$ is positively correlated and significant with ROA, but not with operating profit. ROA is positively correlated and significant with Tobin q, ROE, and operating profit. Operating profit is positively and significantly correlated with ROA. So, all the performance variables are positively correlated with each other but relationship between Tobin $\mathrm{q}$ and operating profit is insignificant.

$$
Y_{i t}=a_{i}+\beta X_{i t}+\mu_{i t}
$$

Using the Hausman Test, to decide whether we treat $a_{i}$ as fixed or random?

$\mathrm{H}_{04}$ : Random tests are independent of explanatory variables.

The results of the Hausman Random Effect Model are shown in Tables 7-9. As the $p$ value is greater than 0.05 in all three situations examined above, Random tests are independent of explanatory variables. As a result, the results support the RE model. The RE and FE estimators of $\beta$ will converge to the same result if the specific effects are random, but the RE estimator is more efficient.

All the three equations developed are given below:

$$
\begin{aligned}
& \mathrm{D}(\text { TOBINQ_MP })=\mathrm{C}(1)+\mathrm{C}(2) * \text { TMSH_CG }+\mathrm{C}(3) * \text { LISH_CG } \\
& +\mathrm{C}(4) * \text { INSH_CG + C }(5) * \text { IND_CG } \\
& +\mathrm{C}(6) * \text { CDLTY_CG +C }(7) * \text { BS_CG } \\
& +\mathrm{C}(8) * \text { AQ_CG + C }(9) * \text { LEVRG } \\
& \mathrm{D}(\text { ROA_FP })=\mathrm{C}(10)+\mathrm{C}(2) * \text { TMSH_CG }+\mathrm{C}(3) * \mathrm{LISH} \_\mathrm{CG} \\
& +\mathrm{C}(4) * \text { INSH_CG +C }(5) * \text { IND_CG } \\
& +\mathrm{C}(6) * \text { CDLTY_CG +C(7)*BS_CG } \\
& +\mathrm{C}(8) * \text { AQ_CG }+\mathrm{C}(9) * \text { LEVRG }
\end{aligned}
$$


Table 4. Heteroskedasticity using White test (LEVRG and CG with OP).

\begin{tabular}{cccc}
\hline Source & $\mathrm{Chi}^{2}$ & Df & $\boldsymbol{P}$ \\
\hline Heteroskedasticity & 22.720 & 30 & 0.827 \\
Skewness & 8.480 & 8 & 0.388 \\
Kurtosis & 1.190 & 1 & 0.274 \\
Total & 32.390 & 39 & 0.764
\end{tabular}

Significance at $5 \%$.

Table 5. Heteroskedasticity using White test (LEVRG and CG with ROA).

\begin{tabular}{cccc}
\hline Source & $\mathrm{Chi}^{2}$ & $\mathrm{df}$ & $\boldsymbol{p}$ \\
\hline Heteroskedasticity & 33.330 & 30 & 0.308 \\
Skewness & 5.810 & 8 & 0.669 \\
Kurtosis & 0.250 & 1 & 0.615 \\
Total & 39.390 & 39 & 0.453 \\
\hline
\end{tabular}

Significance at $5 \%$.

Table 6. Correlation matrix of dependent variables.

\begin{tabular}{ccccc}
\hline & & Tobin Q & $\begin{array}{c}\text { Return } \\
\text { on Assets }\end{array}$ & $\begin{array}{c}\text { Operating } \\
\text { Profit Ratio }\end{array}$ \\
\hline & Pearson Correlation & 1 & $0.396^{* *}$ & 0.220 \\
Tobin Q & Sig. (2-tailed) & & 0.001 & 0.071 \\
& N & 69 & 69 & 68 \\
\hline Return on Assets & Sig. (2-tailed) & 0.001 & & $0.419^{* *}$ \\
& N & 69 & 70 & 0.000 \\
\hline Operating & Pearson Correlation & 0.220 & $0.419^{* *}$ & 1 \\
Profit Ratio & Sig. (2-tailed) & 0.071 & 0.000 & \\
& N & 68 & 69 & 69 \\
\hline
\end{tabular}

Significance at $5 \%$.

Table 7. Hausman test with-ROA as dependent variable.

\section{Correlated Random Effects-Hausman Test}

Equation: United

Test period random effects

\begin{tabular}{cccc}
\hline Test Summary & Chi-Sq. Statistics & Chi-Sq. d.f. & Prob. \\
\hline $\begin{array}{c}\text { Period Random } \\
\end{array}$ & 0.000000 & 8 & 1.0000 \\
& ${ }^{*}$ Period test variance is invalid. Hausman statistic set to zero & \\
& $*$ WARNING: estimated period random effects variance is zero \\
& \\
Period random effects test comparisons: &
\end{tabular}




\section{Continued}

\begin{tabular}{|c|c|c|c|c|}
\hline Variable & Fixed & Random & Var (Diff.) & Prob. \\
\hline AQ_CG & 0.261478 & 0.262261 & 0.000210 & 0.9570 \\
\hline BS_CG & 0.055606 & 0.059017 & 0.000011 & 0.2988 \\
\hline CDLTY_CG & 0.067771 & 0.077369 & 0.000059 & 0.2128 \\
\hline IND_CG & 0.022535 & 0.022203 & 0.000000 & 0.4984 \\
\hline INSH_CG & 0.185175 & 0.201269 & 0.000122 & 0.1453 \\
\hline LEVRG & -0.027539 & -0.012963 & 0.000320 & 0.4151 \\
\hline LISH_CG & 0.013942 & 0.016741 & 0.000003 & 0.1115 \\
\hline TMSH_CG & 0.005947 & 0.002962 & 0.000009 & 0.3297 \\
\hline & $\begin{array}{r}\text { Period rand } \\
\text { Depende } \\
\text { Method: } \\
\text { San } \\
\text { Peri } \\
\text { Cross-s } \\
\text { otal panel (un }\end{array}$ & $\begin{array}{l}\text { cts test equa } \\
\text { able: ROA I } \\
\text { Least Square } \\
09-2018 \\
\text { luded: } 10 \\
\text { included: } 7 \\
\text { ed) observat }\end{array}$ & & \\
\hline Variable & Coefficient & Std. Error & t-statistics & Prob. \\
\hline $\mathrm{C}$ & 0.512316 & 2.686086 & 0.190730 & 0.8495 \\
\hline AQ_CG & 0.261478 & 0.140776 & 1.857414 & 0.0691 \\
\hline BS_CG & 0.055606 & 0.027688 & 2.008326 & 0.0500 \\
\hline CDLTY_CG & 0.067771 & 0.136055 & 0.498112 & 0.6206 \\
\hline IND_CG & 0.022535 & 0.005042 & 4.469856 & 0.0000 \\
\hline INSH_CG & 0.185175 & 0.046054 & 4.020866 & 0.0002 \\
\hline LEVRG & -0.027539 & 0.027391 & -1.005409 & 0.3195 \\
\hline LISH_CG & 0.013942 & 0.007170 & 1.944515 & 0.0575 \\
\hline TMSH_CG & 0.005947 & 0.006547 & 0.908326 & 0.3681 \\
\hline \multicolumn{5}{|c|}{ Effects specification } \\
\hline \multicolumn{5}{|c|}{ Period fixed (dummy variables) } \\
\hline R-squared & 0.625759 & Mean de & nt var & 1.336912 \\
\hline Adjusted R-squared & 0.498517 & S.D. dep & at var & 0.449515 \\
\hline S.E. of regression & 0.318326 & Akaike in & terion & 0.770445 \\
\hline Sum squared resid & 5.066571 & Schwar & rion & 1.357962 \\
\hline Log likelihood & -8.195142 & Hannan- & criter & 1.003237 \\
\hline F-statistic & 4.917864 & Durbin- & n stat & 0.879559 \\
\hline Prob(F-statistic) & 0.000005 & & & \\
\hline
\end{tabular}


Table 8. Hausman test with Tobin Q as dependent variable.

\begin{tabular}{|c|c|c|c|c|}
\hline \multicolumn{5}{|c|}{$\begin{array}{c}\text { Correlated Random Effects-Hausman Test } \\
\text { Equation: United } \\
\text { Test period random effects }\end{array}$} \\
\hline \multicolumn{2}{|c|}{ Test Summary } & Chi-Sq. Statistics & Chi-Sq. d.f. & Prob. \\
\hline \multicolumn{2}{|c|}{ Period Random } & 0.000000 & 8 & 1.0000 \\
\hline \multicolumn{5}{|c|}{$\begin{array}{l}{ }^{\star} \text { Period test variance is invalid. Hausman statistic set to zero. } \\
\text { Period random effects test comparisons: }\end{array}$} \\
\hline Variable & Fixed & Random & Var(Diff.) & Prob. \\
\hline AQ_CG & 0.094895 & 0.095295 & 0.000006 & 0.8704 \\
\hline BS_CG & 0.013504 & 0.013282 & 0.000000 & 0.7401 \\
\hline CDLTY_CG & 0.060861 & 0.061076 & 0.000002 & 0.8821 \\
\hline IND_CG & 0.002675 & 0.002768 & 0.000000 & 0.4476 \\
\hline INSH_CG & 0.030617 & 0.030770 & 0.000004 & 0.9385 \\
\hline LEVRG & 0.010921 & 0.010062 & 0.000011 & 0.7956 \\
\hline LISH_CG & 0.004562 & 0.004425 & 0.000000 & 0.6864 \\
\hline TMSH_CG & 0.000394 & 0.000626 & 0.000000 & 0.6888 \\
\hline \multicolumn{5}{|c|}{ Period random effects test equation: } \\
\hline \multicolumn{5}{|c|}{ Dependent Variable: TOBINQ_MP } \\
\hline \multicolumn{5}{|c|}{ Method: Panel Least Squares } \\
\hline \multicolumn{5}{|c|}{ Sample 2009-2018 } \\
\hline \multicolumn{5}{|c|}{ Periods included: 10} \\
\hline \multicolumn{5}{|c|}{ Cross-sections included: 7} \\
\hline \multicolumn{5}{|c|}{ Total panel (unbalanced) observations: 68} \\
\hline Variable & Coefficient & Std. Error & t-statistics & Prob. \\
\hline $\mathrm{C}$ & -0.654377 & 0.551844 & -1.185803 & 0.2414 \\
\hline AQ_CG & 0.094895 & 0.028934 & 3.279710 & 0.0019 \\
\hline BS_CG & 0.013504 & 0.005848 & 2.308958 & 0.0252 \\
\hline CDLTY_CG & 0.060861 & 0.027985 & 2.174791 & 0.0345 \\
\hline IND_CG & 0.002675 & 0.001051 & 2.545520 & 0.0141 \\
\hline INSH_CG & 0.030617 & 0.009461 & 3.236177 & 0.0022 \\
\hline LEVRG & 0.010921 & 0.005630 & 1.939872 & 0.0582 \\
\hline LISH_CG & 0.004562 & 0.001484 & 3.075204 & 0.0034 \\
\hline TMSH_CG & 0.000394 & 0.001359 & 0.289559 & 0.7734 \\
\hline \multicolumn{5}{|c|}{ Effects specification } \\
\hline \multicolumn{5}{|c|}{ Period fixed (dummy variables) } \\
\hline R-squared & 0.539090 & Mean depen & ent var & 1.052560 \\
\hline Adjusted R-squared & 0.379182 & S.D. depend & nt var & 0.082997 \\
\hline
\end{tabular}




\section{Continued}

\begin{tabular}{cccc}
\hline S.E. of regression & 0.065395 & Akaike info criterion & -2.392309 \\
Sum squared resid & 0.209547 & Schwarz criterion & -1.800003 \\
Log likelihood & 98.14235 & Hannan-Quinn criter & -2.157932 \\
F-statistic & 3.371259 & Durbin-Watson stat & 1.560730 \\
Prob (F-statistic) & 0.000394 & & \\
\hline
\end{tabular}

Table 9. Hausman test with-ROA as dependent variable.

\section{Correlated Random Effects-Hausman Test}

Equation: United

Test period random effects

\begin{tabular}{|c|c|c|c|c|}
\hline \multicolumn{2}{|c|}{ Test Summary } & Chi-Sq. Statistics & Chi-Sq. d.f. & Prob. \\
\hline \multicolumn{2}{|c|}{ Period Random } & 0.000000 & 8 & 1.0000 \\
\hline \multicolumn{5}{|c|}{$\begin{array}{l}{ }^{\star} \text { Period test variance is invalid. Hausman statistic set to zero. } \\
\text { Period random effects test comparisons: }\end{array}$} \\
\hline Variable & Fixed & Random & Var (Diff.) & Prob. \\
\hline AQ_CG & 44.208799 & 42.753443 & 42.753443 & 0.4122 \\
\hline BS_CG & 6.439198 & 5.666552 & 5.666552 & 0.1376 \\
\hline CDLTY_CG & 7.399612 & 4.383844 & 4.383844 & 0.1614 \\
\hline IND_CG & 2.411155 & 2.548100 & 2.548100 & 0.1816 \\
\hline INSH_CG & 3.976908 & 1.747053 & 1.747053 & 0.2000 \\
\hline LEVRG & -7.232945 & -11.157902 & -11.157902 & 0.1643 \\
\hline LISH_CG & -0.456500 & -0.576441 & -0.576441 & 0.6677 \\
\hline TMSH_CG & 1.726647 & 2.124872 & 2.124872 & 0.4088 \\
\hline
\end{tabular}

Period random effects test equation:

Dependent Variable: OP_OPR

Method: Panel Least Squares

Sample 20092018

Periods included: 10

Cross-sections included: 7

Total panel (unbalanced) observations: 68

$\begin{array}{ccccc}\text { Variable } & \text { Coefficient } & \text { Std. Error } & \text { t-statistics } & \text { Prob. } \\ \text { C } & 478.1214 & 430.7207 & 1.110050 & 0.2724 \\ \text { AQ_CG } & 44.208799 & 22.69168 & 1.948238 & 0.0571 \\ \text { BS_CG } & 6.439198 & 4.440835 & 1.449997 & 0.1534 \\ \text { CDLTY_CG } & 7.399612 & 22.19667 & 0.333366 & 0.7403 \\ \text { IND_CG } & 2.411155 & 0.835731 & 2.885081 & 0.0058 \\ \text { INSH_CG } & 3.976908 & 7.387205 & 0.538351 & 0.5928 \\ \text { LEVRG } & -7.232945 & 4.395095 & -1.645685 & 0.1062\end{array}$




\begin{tabular}{|c|c|c|c|c|}
\hline \multicolumn{5}{|l|}{ Continued } \\
\hline LISH_CG & -0.456500 & 1.150647 & -0.396734 & 0.6933 \\
\hline TMSH_CG & 1.726647 & 1.050084 & 1.644292 & 0.1065 \\
\hline \multicolumn{5}{|c|}{ Effects specification } \\
\hline \multicolumn{5}{|c|}{ Period fixed (dummy variables) } \\
\hline R-squared & 0.545769 & \multicolumn{2}{|c|}{ Mean dependent var } & 109.3379 \\
\hline Adjusted R-squared & 0.388178 & \multicolumn{2}{|c|}{ S.D. dependent var } & 65.26069 \\
\hline S.E. of regression & 51.04628 & \multicolumn{2}{|c|}{ Akaike info criterion } & 10.92778 \\
\hline Sum squared resid & 127680.4 & \multicolumn{2}{|c|}{ Schwarz criterion } & 11.52009 \\
\hline Log likelihood & -348.0807 & \multicolumn{2}{|c|}{ Hannan-Quinn criter } & 11.16216 \\
\hline F-statistic & 3.463209 & \multicolumn{2}{|c|}{ Durbin-Watson stat } & 1.313357 \\
\hline Prob (F-statistic) & 0.000339 & & & \\
\hline
\end{tabular}

$$
\begin{aligned}
\mathrm{D}\left(\mathrm{OP} \_\mathrm{OPR}\right)= & \mathrm{C}(11)+\mathrm{C}(2) * \mathrm{TMSH} \_\mathrm{CG}+\mathrm{C}(3) * \mathrm{LISH} \_\mathrm{CG} \\
& +\mathrm{C}(4) * \mathrm{INSH} \_\mathrm{CG}+\mathrm{C}(5) * \mathrm{IND} \_\mathrm{CG} \\
& +\mathrm{C}(6) * \mathrm{CDLTY} \mathrm{CG}+\mathrm{C}(7) * \mathrm{BS} \_\mathrm{CG} \\
& +\mathrm{C}(8) * \mathrm{AQ} \_\mathrm{CG}+\mathrm{C}(9) * \mathrm{LEVRG}
\end{aligned}
$$

$\mathrm{H}_{05}$ : Independent variables are exogeneous.

Many fields of business and management study that rely on regression analysis to draw causal inference are concerned about endogeneity which is a crucial assumption in for every Classical Linear Regression Model (CLRM). The Durbin-Wu-Hausman test (augmented regression test) or Hausman Specification test is used to test Endogeneity. Once we get the evidence of Endogeneity, we will use TSLS (Two Stage Least Square) instead of OLS to get unbiased and consistent results asymptotically.

As evident from the results the following few of the latent variables Corporate Governance had endogeneity. Therefore, we will use TSLS instead of OLS. Following are the results of the endogeneity test (Durbin-WU-Hausman Test) showing the endogenous variables in our three equations with different dependent variables such as ROA, Tobin Q and Operating Profits.

Table 10 shows the results of the Durbin Wu-Hausman Endogeneity Test among the independent variables. A few independent variables with $p$ values less than 0.05 indicate endogeneity, indicating that the null hypothesis is rejected. This test helps us decide whether to use OLS or TSLS. We have found the endogeneity among our independent variables, so we will use TSLS.

Due to endogeneity among our independent variables, we will apply the TSLS. The results of TSLS for all the three dependent variables are as follows:

First table is showing results of TSLS with ROA_FP, second one for the operating profit and third one is with Tobin $\mathrm{Q}$ as dependent variable (Table 11). 
Table 10. Results of Durbin Wu-Hausman endogeneity test.

\begin{tabular}{ccccccc}
\hline Dependent Variable & \multicolumn{2}{c}{ OP_OPR } & \multicolumn{2}{c}{ Tobin Q } & \multicolumn{2}{c}{ ROA } \\
\hline $\begin{array}{c}\text { Independent } \\
\text { Variables }\end{array}$ & $\begin{array}{c}\text { Durbin } \\
\text { Score } \\
\text { Chi2 }\end{array}$ & $\begin{array}{c}\text { Wu- } \\
\text { Hausman }\end{array}$ & $\begin{array}{c}\text { Durbin } \\
\text { Score } \\
\text { Chi2 }\end{array}$ & $\begin{array}{c}\text { Wu- } \\
\text { Hausman }\end{array}$ & $\begin{array}{c}\text { Durbin } \\
\text { Score } \\
\text { Chi2 }\end{array}$ & $\begin{array}{c}\text { Wu- } \\
\text { Hausman }\end{array}$ \\
\hline Ind_CG & 0.8548 & 0.8548 & 0.4930 & 0.5074 & 0.9352 & 0.9295 \\
CDLTY_CG & 0.9056 & 0.9056 & 0.5050 & 0.5152 & 0.5893 & 0.6511 \\
AQ_CG & $\mathbf{0 . 0 4 0 1 ^ { * }}$ & $\mathbf{0 . 0 4 0 1 *}$ & 0.8498 & 0.8542 & 0.3875 & 0.4141 \\
BS_CG & 0.2991 & 0.2991 & 0.8490 & 0.8532 & 0.2519 & 0.2779 \\
LISH_CG & 0.6308 & 0.6308 & 0.5680 & 0.5811 & $\mathbf{0 . 0 2 9 6 *}$ & $\mathbf{0 . 0 3 6 8 *}$ \\
INSH_CG & 0.5543 & 0.5543 & $\mathbf{0 . 0 0 0 0 *}$ & $\mathbf{0 . 0 0 0 0 *}$ & $\mathbf{0 . 0 0 0 5 *}$ & $\mathbf{0 . 0 0 0 6}$ \\
TMSH_CG & 0.4586 & 0.4586 & 0.8492 & 0.8357 & 0.0579 & 0.0700 \\
LEVRG & 0.0270 & 0.0334 & 0.9990 & 0.1085 & 0.9078 & 0.9812 \\
\hline
\end{tabular}

Significance at $5 \%$. ${ }^{\star}$ Variables where endogeneity exist.

Table 11. TSLS with "ROA_FP” as dependent variable.

\begin{tabular}{|c|c|c|c|c|c|c|}
\hline \multicolumn{7}{|c|}{ Instrumental variables (2SLS) Regression } \\
\hline Source & SS & df & \multicolumn{2}{|c|}{ MS } & Number of obs $=$ & 68 \\
\hline Model & 7.92314348 & 8 & \multicolumn{2}{|c|}{0.990392935} & $\mathrm{~F}(8,59)=$ & 10.41 \\
\hline Residual & 5.61510799 & 59 & \multicolumn{2}{|c|}{0.095171322} & Prob $>F=$ & 0.000 \\
\hline \multirow[t]{3}{*}{ Total } & 13.5382515 & 67 & \multicolumn{2}{|c|}{0.202063455} & R-squared $=$ & 0.5852 \\
\hline & & & & & Adj R-squared= & 0.5290 \\
\hline & & & & & Root MSE $=$ & 0.3085 \\
\hline ROA_FP & Coef. & Std. Err. & $\mathrm{t}$ & $p>|\mathrm{t}|$ & [95\% Conf. & Interval] \\
\hline CDLTY_CG & 0.0773686 & 0.13136435 & 0.59 & 0.559 & -0.1860494 & 0.3407865 \\
\hline AQ_CG & 0.2622609 & 0.1357035 & 1.93 & 0.058 & -0.0092811 & 0.533803 \\
\hline BS_CG & 0.0590171 & 0.0266435 & 2.22 & 0.031 & 0.0057035 & 0.1123307 \\
\hline INSH_CG & 0.2012691 & 0.0433278 & 4.65 & 0.000 & 0.1145705 & 0.2879677 \\
\hline IND_CG & 0.022203 & 0.0048627 & 4.57 & 0.000 & 0.0124726 & 0.0319333 \\
\hline LEVRG & -0.0129635 & 0.020104 & -0.64 & 0.522 & -0.0531915 & 0.0272645 \\
\hline TMSH_CG & 0.0029621 & 0.0056082 & 0.53 & 0.599 & -0.0082598 & 0.014184 \\
\hline LISH_CG & 0.0167414 & 0.0067361 & 2.49 & 0.016 & 0.0032626 & 0.0302203 \\
\hline _cons & -0.8887051 & 2.095129 & -0.42 & 0.673 & -5.081049 & 3.303639 \\
\hline \multicolumn{2}{|c|}{ Mean dependent var } & 1.337 & \multicolumn{2}{|c|}{ SD dependent var } & 0.450 & \\
\hline \multicolumn{2}{|c|}{ R-squared } & 0.585 & \multicolumn{2}{|c|}{ Number of obs } & 68 & \\
\hline \multicolumn{2}{|c|}{ F-test } & 10.406 & \multicolumn{2}{|c|}{ Prob $>$ F } & 0.000 & \\
\hline \multicolumn{5}{|c|}{$\begin{array}{c}{ }^{* *} p<0.01,{ }^{* *} p<0.05,{ }^{*} p<0.1 . \\
\text { No endogenous variable }\end{array}$} & & \\
\hline
\end{tabular}

Significance at $5 \%$. 
Estimated Equation:

$$
\begin{aligned}
\text { D }(\text { ROA_FP })= & \mathrm{C}(10)+\mathrm{C}(2) * \mathrm{TMSH}+\mathrm{CG}+\mathrm{C}(3) * \mathrm{LISH} \_\mathrm{CG} \\
& +\mathrm{C}(4) * \mathrm{INSH} \mathrm{CG}+\mathrm{C}(5) * \mathrm{IND} \_\mathrm{CG} \\
& +\mathrm{C}(6) * \mathrm{CDLTY} \mathrm{CG}+\mathrm{C}(7) * \mathrm{BS} \_\mathrm{CG} \\
& +\mathrm{C}(8) * \mathrm{AQ} \text { CG }+\mathrm{C}(9) * \mathrm{LEVRG}
\end{aligned}
$$

Substituted Coefficients:

$$
\begin{aligned}
\text { ROA_FP } & =0.00296621 * \text { TMSH_CG }+0.167414 * \text { LISH_CG } \\
& +0.2012691 * \text { INSH_CG }+0.0022203 * \text { IND_CG } \\
& +0.0773686 * \text { CDLTY_CG }+0.0590171 * \text { BS_CG } \\
& +0.2622609 * \text { AQ_CG }+0.0129635 * \text { LEVRG }-0.8887051
\end{aligned}
$$

\begin{tabular}{|c|c|c|c|c|c|c|}
\hline \multicolumn{7}{|c|}{ Instrumental variables (2SLS) Regression } \\
\hline Source & SS & df & \multicolumn{2}{|c|}{ MS } & Number of obs $=$ & 67 \\
\hline Model & 132890.301 & 8 & \multicolumn{2}{|c|}{16611.2877} & $F(8,59)=$ & 6.50 \\
\hline Residual & 148200.867 & 58 & \multicolumn{2}{|c|}{2555.18737} & Prob $>F=$ & 0.000 \\
\hline \multirow[t]{3}{*}{ Total } & 281091.169 & 66 & \multicolumn{2}{|c|}{4258.9571} & R-squared= & 0.4728 \\
\hline & & & & & Adj R-squared= & 0.4000 \\
\hline & & & & & Root MSE $=$ & 50.549 \\
\hline OP_OPR & Coef. & Std. Err. & $\mathbf{t}$ & $p>|t|$ & [95\% Conf. & Interval] \\
\hline CDLTY_CG & 4.223933 & 21.87076 & 0.19 & 0.848 & -39.55516 & 48.00302 \\
\hline AQ_CG & 42.70357 & 22.398 & 1.91 & 0.062 & -2.130886 & 87.53803 \\
\hline BS_CG & 5.630698 & 4.265698 & 1.29 & 0.202 & -3.108177 & 14.36957 \\
\hline INSH_CG & 1.655147 & 7.09945 & 0.23 & 0.816 & -12.55595 & 15.86624 \\
\hline IND_CG & 2.553777 & 0.8210446 & 3.11 & 0.003 & 0.9102772 & 4.197276 \\
\hline LEVRG & -11.30039 & 3.294696 & -3.43 & 0.001 & -17.89544 & -4.705341 \\
\hline TMSH_CG & 2.133993 & 0.9190169 & 2.32 & 0.024 & 0.294381 & 3.973605 \\
\hline LISH_CG & -0.5767633 & 1.103746 & -0.52 & 0.603 & -2.786152 & 1.632625 \\
\hline _cons & 839.8042 & 343.6211 & 2.44 & 0.018 & 151.9718 & 1527.636 \\
\hline \multicolumn{2}{|c|}{ Mean dependent var } & 109.338 & \multicolumn{2}{|c|}{ SD dependent var } & 65.261 & \\
\hline \multicolumn{2}{|c|}{ R-squared } & 0.473 & \multicolumn{2}{|c|}{ Number of obs } & 67 & \\
\hline \multicolumn{2}{|c|}{ F-test } & 6.501 & \multicolumn{2}{|c|}{ Prob $>$ F } & 0.000 & \\
\hline \multicolumn{5}{|c|}{$\begin{array}{l}{ }^{* *} p<0.01,{ }^{* *} p<0.05,{ }^{*} p<0.1 \\
\text { No endogenous variable }\end{array}$} & & \\
\hline
\end{tabular}

Value of $\mathrm{R}^{2}$ (Coefficient of Determination) is 0.5852 which means that one unit change in "independent variable" will bring $58.52 \%$ change in the dependent variable which is Return on Asset in the above-mentioned case.

Table 12 is showing results of TSLS with OP_OPR as dependent variable., second one for the operating profit and third one is with Tobin Q as dependent variable.

Table 12. TSLS with "OP_OPR” as dependent variable.

Significance at $5 \%$. 


\section{Estimated Equation}

$$
\begin{aligned}
\mathrm{D}\left(\mathrm{OP} \_O P R\right)= & \mathrm{C}(11)+\mathrm{C}(2) * \mathrm{TMSH} \_\mathrm{CG}+\mathrm{C}(3) * \mathrm{LISH} \_\mathrm{CG} \\
& +\mathrm{C}(4) * \mathrm{INSH} \_\mathrm{CG}+\mathrm{C}(5) * \mathrm{IND} \_\mathrm{CG} \\
& +\mathrm{C}(6) * \mathrm{CDLTY} C \mathrm{CG}+\mathrm{C}(7) * \mathrm{BS} \_\mathrm{CG} \\
& +\mathrm{C}(8) * \mathrm{AQ} \text { CG }+\mathrm{C}(9) * \mathrm{LEVRG}
\end{aligned}
$$

Substituted Coefficients:

$$
\begin{aligned}
\text { OP_OPR }= & 2.133993 * \text { TMSH_CG }-0.5767633 * \text { LISH_CG } \\
& +1.655147 * \text { INSH_CG }+2.553777 * \text { IND_CG } \\
& +4.223933 * \text { CDLTY_CG }+5.630698 * \text { BS_CG } \\
& +42.70357 * \text { AQ_CG }-11.30039 * \text { LEVRG }+839.8842
\end{aligned}
$$

\begin{tabular}{|c|c|c|c|c|c|c|}
\hline \multicolumn{7}{|c|}{ Instrumental Variables (2SLS) Regression } \\
\hline Source & SS & df & & IS & Number of obs $=$ & 67 \\
\hline Model & 0.203131985 & 8 & 0.025 & 391498 & $F(8,59)=$ & 5.86 \\
\hline Residual & 0.25150568 & 58 & 0.004 & 336305 & Prob $>F=$ & 0.000 \\
\hline \multirow{3}{*}{ Total } & 0.454637665 & 66 & 0.006 & 888449 & R-squared= & 0.4468 \\
\hline & & & & & Adj R-squared= & 0.3705 \\
\hline & & & & & Root MSE= & .06585 \\
\hline TobinQ & Coef. & Std. Err. & $\mathrm{t}$ & $p>|t|$ & [95\% Conf. & Interval] \\
\hline CDLTY_CG & 0.0611 & 0.0281 & 2.17 & 0.034 & 0.0048292 & 0.1174382 \\
\hline AQ_CG & 0.0956 & 0.0290 & 3.30 & 0.003 & 0.0375373 & 0.1536072 \\
\hline BS_CG & 0.0132 & 0.0058 & 2.26 & 0.027 & 0.0015281 & 0.0248947 \\
\hline INSH_CG & 0.0309 & 0.0099 & 3.34 & 0.001 & 0.123553 & 0.0493908 \\
\hline IND_CG & 0.0028 & 0.0010 & 2.67 & 0.010 & 0.0006993 & 0.0048987 \\
\hline LEVRG & 0.0099 & 0.0043 & 2.31 & 0.025 & 0.001318 & 0.0184999 \\
\hline TMSH_CG & 0.0007 & 0.0012 & 0.58 & 0.567 & -0.0017153 & 0.0031022 \\
\hline LISH_CG & 0.0044 & 0.0014 & 3.03 & 0.004 & 0.0014859 & 0.0072617 \\
\hline _cons & -0.5671 & 0.4474 & -1.27 & 0.210 & -1.462713 & 0.3285621 \\
\hline $\begin{array}{c}\text { Mean } \\
\text { dependent var }\end{array}$ & \multicolumn{2}{|c|}{1.053} & \multicolumn{2}{|c|}{$\begin{array}{l}\text { SD dependent } \\
\text { var }\end{array}$} & \multicolumn{2}{|l|}{0.083} \\
\hline R-squared & \multicolumn{2}{|l|}{0.447} & \multicolumn{2}{|c|}{ Number of obs } & \multicolumn{2}{|l|}{67} \\
\hline F-test & \multicolumn{2}{|c|}{5.856} & Pro & $\mathrm{b}>\mathrm{F}$ & \multicolumn{2}{|l|}{0.000} \\
\hline \multicolumn{7}{|c|}{$\begin{array}{c}{ }^{* *} p<0.01,{ }^{* *} p<0.05,{ }^{*} p<0 \\
\text { No endogenous variable }\end{array}$} \\
\hline
\end{tabular}

Value of $\mathrm{R}^{2}$ (Coefficient of Determination) is 0.4728 which means that one unit change in "independent variable" will bring $47.28 \%$ change in the dependent variable which is operating profit in the above-mentioned case.

Table 13 is showing results of TSLS with TobinQ as dependent variable.

Table 13. TSLS with Tobin Q as dependent variable.

Significance at $5 \%$. 
Due to endogeneity among our independent variables we used TSLS. Tables 11-13 are showing results of TSLS. Hence, estimated equations are mentioned under each table.

Estimated Equation

$$
\begin{aligned}
\text { D }(\text { TOBINQ_MP })= & \mathrm{C}(1)+\mathrm{C}(2) * \text { TMSH_CG }+\mathrm{C}(3) * \text { LISH_CG } \\
& +\mathrm{C}(4) * \mathrm{INSH} \text { _CG }+\mathrm{C}(5) * \mathrm{IND} \_\mathrm{CG} \\
& +\mathrm{C}(6) * \mathrm{CDLTY} \_\mathrm{CG}+\mathrm{C}(7) * \mathrm{BS} \_\mathrm{CG} \\
& +\mathrm{C}(8) * \mathrm{AQ} \text { CG }+\mathrm{C}(9) * \mathrm{LEVRG}
\end{aligned}
$$

Substituted Coefficients:

$$
\begin{aligned}
\text { TOBINQ_MP }= & 0.0007 * \text { TMSH_CG }+0.0044 * \text { LISH_CG } \\
& +0.0309 * \text { INSH_CG }+0.0028 * \text { IND_CG } \\
& +0.0611 * \text { CDLTY_CG }+0.0132 * \text { BS_CG } \\
& +0.0956 * \text { AQ_CG }+0.0099 * \text { LEVRG }-0.5671
\end{aligned}
$$

Value of $\mathrm{R}^{2}$ (Coefficient of Determination) is 0.4468 which means that one unit change in "IV" will bring $44.68 \%$ change in the dependent variable which is Tobin $\mathrm{Q}$ in the above-mentioned case.

Because very few previous research dealt with endogeneity, the OLS was employed for analysis. We looked at endogeneity and used Durbin-Wu-Hausman to determine which variables were endogenous. When the endogeneity problem in OLS is encountered, TSLS is employed as an alternative technique. Then we employ TSLS, which employs instrumental variables. The outcome will be different because if the model has endogeneity, OLS will provide a biased conclusion. The statistical approach of two-stage least squares (TSLS) regression analysis is employed in the investigation of structural equations. This method of estimating the route coefficient in SEM modelling is an alternative. When controlled trials are not possible, TSLS is used in econometrics and statistics to generate consistent estimates of a regression equation. The first stage of two-stage least-squares regression uses instrumental variables that are uncorrelated with the error terms to compute estimated values of the problematic predictor(s), and then the second stage uses instrumental variables that are uncorrelated with the error terms to compute estimated values of the problematic predictor(s).

Now we will check for the impact of mediator CSR on the relation between the Corporate Governance and financial performance.

In order to find out the mediating impact of CSR between the CG and FP our hypotheses will be as follows.

$\mathrm{H}_{06}$ : There is no mediating effect of $\mathrm{M}$ (Mediator: Corporate Social Responsibility-CSR) on relationship between " $\mathrm{X}$ " (Independent Variable-Corporate Governance-CG) and "Y" (Dependent Variable-Financial Performance-FP).

For mediation analysis through SEM, we used the Smart-PLS 3.0. The diagram showing the impact of Independent variables, dependent variables and mediating variable is given below as Figure 2 . 


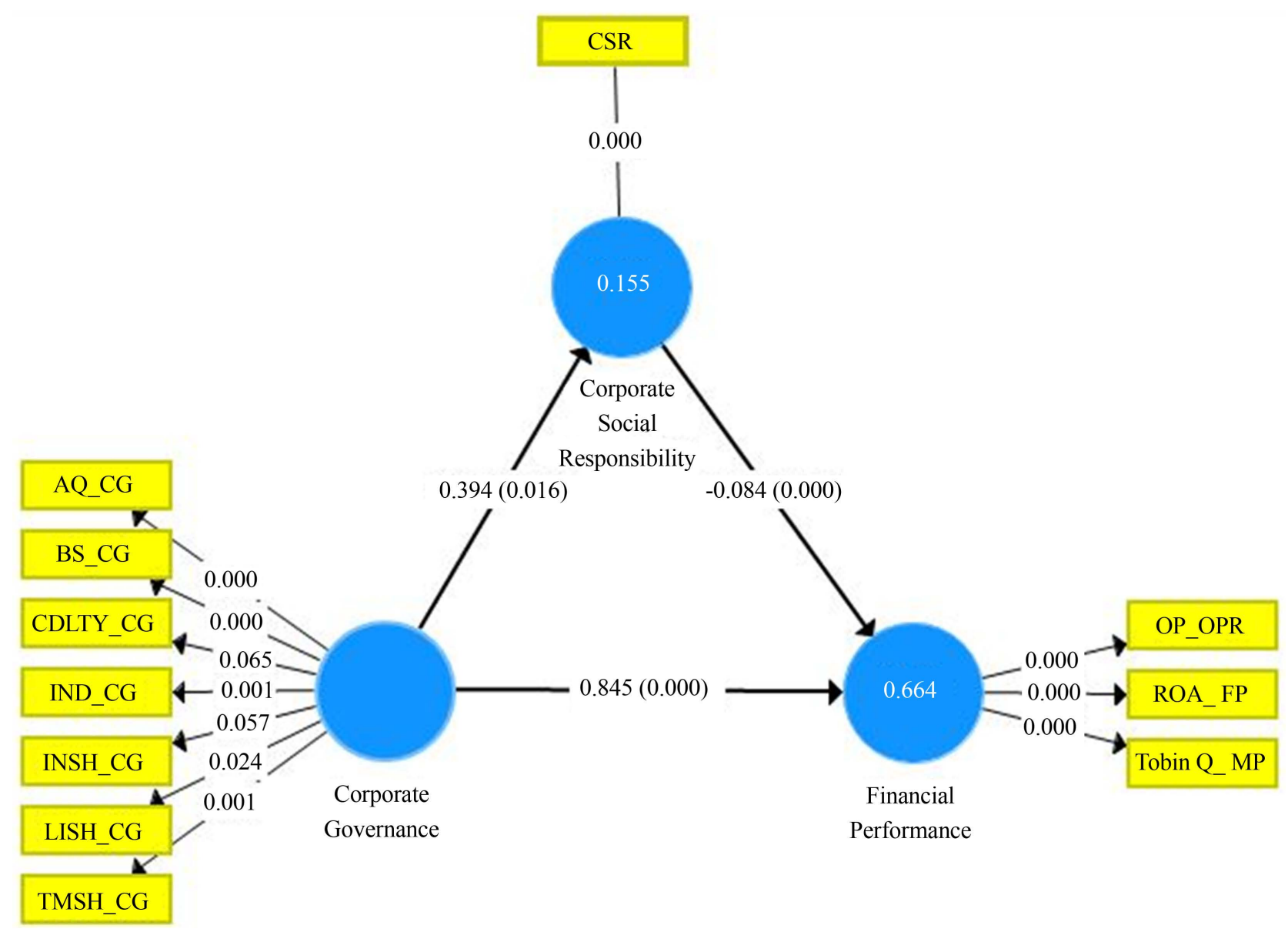

Figure 2. Mediation (Structured Equation Modelling-SEM).

We can see in Figure 2 that relation between CG and CSR, and CG and FP are statistically significant and positive, whereas, coefficients are 0.394 and 0.845 respectively and $p$ values are less than 0.05 . The relation between CSR and FP is also statistically significant but negative and the value of coefficient is -0.084 and $p$ value is also less than 0.05 . Since all these relations are statistically significant, we can conclude that the impact of mediator is there but we call it as partial mediation. We reject the null hypothesis and accept the alternate hypothesis. Value of $R^{2}$ showing the percentage change. The percentage change between the CG and CSR is $15 \%$ whereas, percentage change in CSR and Financial Performance is $66.4 \%$.

Tables 14-16 are showing the result of mediation analaysis using Smart-PLS and includes direct and indirect effects among variables, where CSR is the mediating variable with CG as Independent Variable and Financial Performance as Dependent Variable.

$\mathrm{H}_{07}$ : There is no mediating effect of M (Mediator: Corporate Social Responsibility-CSR) on relationship between " $X$ " (Independent Variable: Leverage_LEVRG) and "Y" (Dependent Variable: Financial Performance-FP).

We can see in Figure 3 that the relation between LEVRG and FP, and CG 
Table 14. Path co-efficients.

\begin{tabular}{ccc}
\hline & $\begin{array}{c}\text { Path } \\
\text { Coefficients }\end{array}$ & $\begin{array}{c}p \\
\text { Values }\end{array}$ \\
\hline Corporate Governance $\rightarrow$ Corporate Social Responsibility & 0.3940 & 0.0160 \\
Corporate Governance $\rightarrow$ Financial_Performance & 0.8450 & 0.0000 \\
Corporate Social Responsibility $\rightarrow$ Financial_Performance & -0.0840 & 0.0000 \\
\hline
\end{tabular}

Significance at $5 \%$.

Table 15. Specific indirect effect.

Indirect Effect

Corporate Governance $\rightarrow$ Coporate_Social_Responsibility $\rightarrow$ Financial_Performance

$-0.033$

Table 16. Total effect.

Total effect

\begin{tabular}{cc}
\hline Corporate Governance $\rightarrow$ Corporate Social Responsibility & 0.3940 \\
Corporate Governance $\rightarrow$ Financial_Performance & 0.8120 \\
Corporate Social Responsibility $\rightarrow$ Financial_Performance & -0.0840 \\
\hline
\end{tabular}

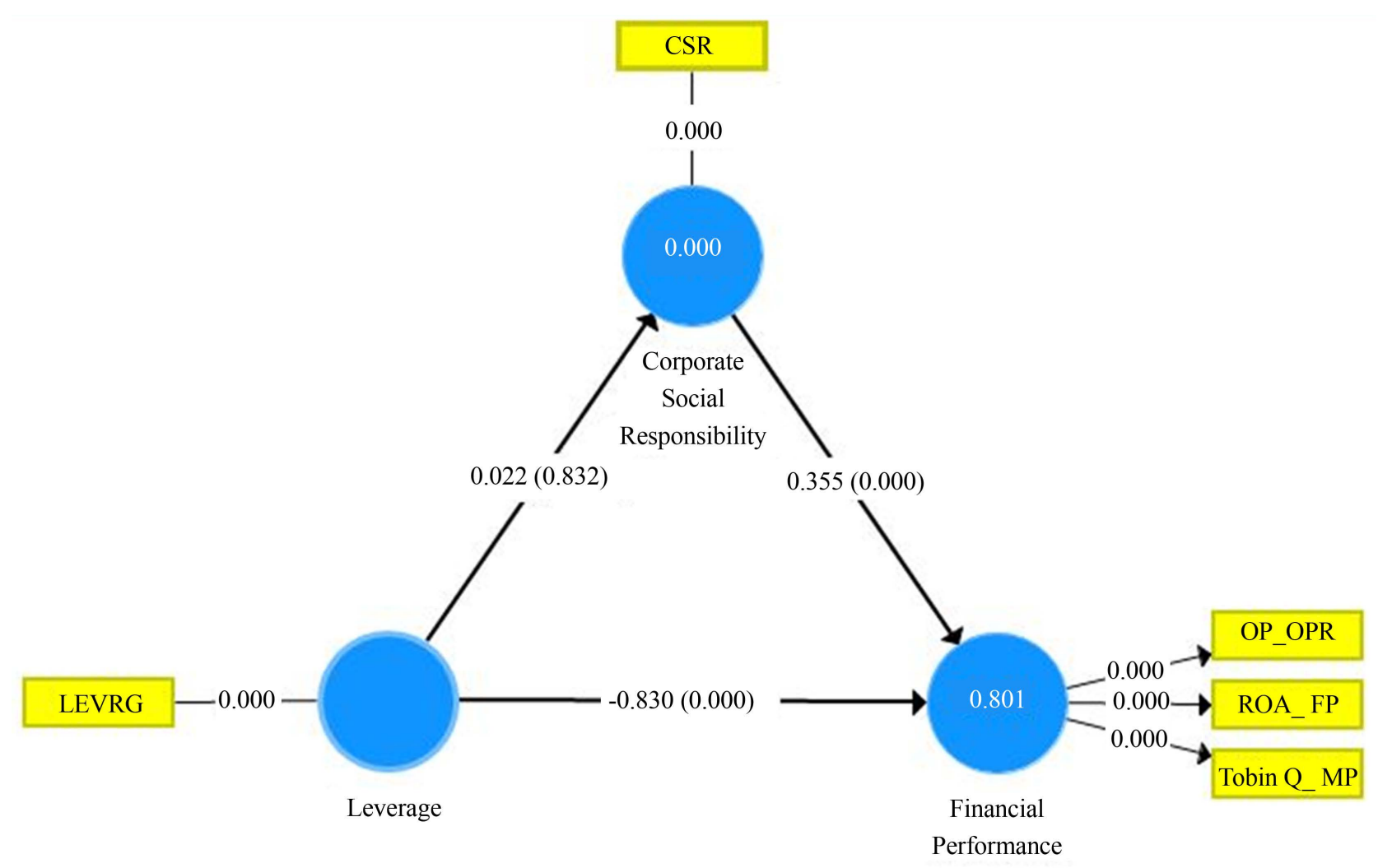

Figure 3. The relation between LEVRG, FP and CSR. 
and FP are statistically significant, whereas, coefficients are 0.355 and -0.845 respectively and $p$ values are less than 0.05 . The statistical test resulted in a negative significant relationship between financial leverage and profitability. The relation between LEVRG and CSR is not statistically significant and the value of coefficient is 0.022 and $p$ value is greater than 0.05 which is 0.832 . Since all these relations are not statistically significant, we can conclude that there is no impact of mediator on the relationship between LEVRG and FP. Therefore, we accept the Null Hypothesis. The value of $\mathrm{R}^{2}$ showing the percentage change. The percentage change between Leverage and CSR is $0.00 \%$ whereas, percentage change in CSR Financial performance is $80.1 \%$.

Tables 17-19 are showing the result of mediation analaysis using Smart-PLS and include direct and indirect effects among variables, where CSR is the mediating variable with Leverage as Independent Variable and Financial Performance as Dependent Variable.

$\mathrm{H}_{08}$ : There is no mediating effect of $\mathrm{M}$ (Mediator: Leverage-CSR) on relationship between " $\mathrm{X}$ " (Independent Variable: Corporate Governance-CG) and "Y" (Dependent Variable: Financial Performance-FP).

Relationship between CG and LEVRG (Figure 4) is negative but insignificant. Relationship between Leverage is negative but statistically significant. CG is having positive but statistically significant relationship with financial performance.

Table 17. Total effect.

\begin{tabular}{ccc}
\hline & Total effect & $p$ Values \\
\hline Corporate Social Responsibility $\rightarrow$ Financial_Performance & 0.3350 & 0.0000 \\
Leverage $\rightarrow$ Corporate_Social_Responsibility & 0.0220 & 0.8320 \\
Leverage $\rightarrow$ Financial_Performance & -0.8300 & 0.0000 \\
\hline
\end{tabular}

Significance at $5 \%$.

Table 18. Total indirect effect.

Indirect Effect

Coporate_Social_Responsibility $\rightarrow$ Financial_Performance

Leverage $\rightarrow$ Corporate_Social_Responsibility

Leverage $\rightarrow$ Financial_Performance

0.008

Table 19. Total effect.

\begin{tabular}{cc}
\hline & Total Effect \\
\hline Coporate_Social_Responsibility $\rightarrow$ Financial_Performance & 0.355 \\
Leverage $\rightarrow$ Corporate_Social_Responsibility & 0.022 \\
Leverage $\rightarrow$ Financial_Performance & 0.008
\end{tabular}




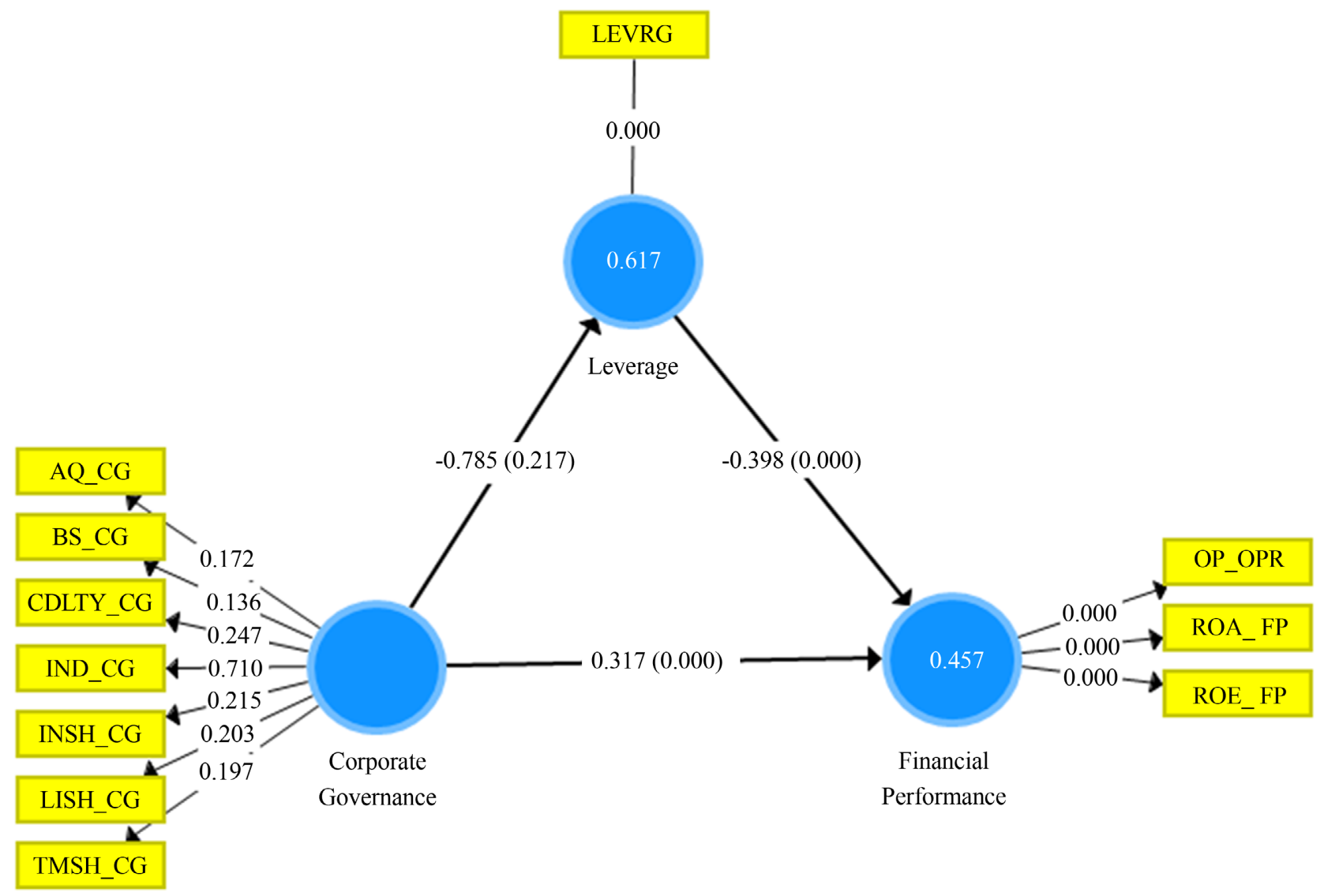

Figure 4. Relationship between CG with LEVRG and FP.

\subsection{Summary of Research Results and Findings}

There is a statistically significant relation between CG and Financial performance of the banks. Overall relation of CG with financial performance was significant. CG is also statistically significant and positive relation with CSR, whereas, CSR is statistically significant but negative relation with financial performance. This confirms the existence of the role of CSR as a mediator.

Leverage is negatively correlated and significant with financial performance. CSR is also a statistically significant positive relation with financial performance but leverage does not have a statistically significant relation with CSR. In both the models mentioned above the importance of CSR has been highlighted as a mediator.

\subsection{Discussion}

The investigation of corporate governance and leverage with CSR as a mediating variable on performance of local banks of local Thailand shows the hidden significance of many relationships. Results of our study validated the results of the study of (Klapper \& Love, 2004) which found a positive relationship was found between CG and ROA. CG and CSR have a positively significant relationship. This result conforms to the research done by (Mc Williams \& Siegel, 2018) 
which stated CSR can enhance various stakeholders' relationships. In this case our alternate $\mathrm{H}_{06}$ is accepted.

Leverage has a negative and significant relationship with financial performance that validates the findings of the earlier research study by (Ramzan et al., 2021) which stated that high level of leverage is the cause of reduction in financial stability. This was also confirmed through the study of Zhou et al. (2021) which states that high profitable companies have sufficient funds and are not dependent on external debt. Our findings confirmed that negative relationships exist between financial performance and financial leverage. Therefore, there is no mediation between Leverage and FP. In this case our Null Hypothesis $\mathrm{H}_{07}$ is validated and confirmed.

Results of the study by Singapurwoko \& El-Wahid (2011) show that debt (leverage) in general has a significant effect on companies' profitability. According to Hong \& Sullivan (2013) debt financing puts pressure on managers to compel them to perform efficiently and this results in high corporate performance, however these results are contrary to the results of our study. Moreover, the result of the study of Zhou et al. (2021) also indicated that financial leverage has a negative impact on the firm's financial performance. We should not forget that debt is not the only reason behind company profitability, as there are many other macroeconomic factors that affect performance of a company.

Our results further confirm the earlier findings of Bannier et al. (2021) that determined Credit rating agencies tend to award comparatively high ratings to firms with good social performance. We should not forget that companies with higher credit rating can get the debt on soft terms and conditions having less burden on the financial results. CSR provides the important non-financial information that credit rating agencies use in their evaluation. Our study further substantiates the results by Kim et al. (2017) and Ullah et al. (2020). According to the findings of the Ullah et al. (2020) study, supporting corporate social responsibility (CSR) has become an important part of a company's marketing strategy. CSR efforts lead to positive organizational outcomes such as improved corporate reputation, customer loyalty, and performance.

Voluntary actions of CSR have a positive effect on the interest of primary stakeholders and this will boost the firm's competitiveness and reputation. Over investment theory states that top management used CSR practices to enhance their private gains to social citizen reputation. According to Yadav et al. (2018), CSR and CG play an important role in developing countries' long-term growth. Results of our study confirm that CG is having a significant impact on the financial performance of the banks.

\section{Conclusion}

Local Thai banks need to focus more on such corporate social responsibility activities which can add to their public image and ultimately create a positive impact on their profitability and overall financial performance. Based on the find- 
ings of our study we can recommend that Thai banks should focus more on the CSR activities in future and our study shows a significant but negative relationship between CSR and financial performance. The link between excellent corporate governance and corporate social responsibility supports businesses in maintaining a healthy balance. It also backs the company's efforts to improve control systems, increase shareholder value, and improve shareholder and stakeholder satisfaction. Therefore, the management of banks should give more emphasis on these factors in order to achieve overall good performance and financial results.

\subsection{Research Limitations}

1) Different modes of collecting data were not used to know the real scenario.

2) This study concentrated only on local banks in Thailand. Foreign banks working or operating in Thailand were not considered, which might restrict the generalization of research results.

3) This study uses three measures for financial performance (ROA, Operating Profit and TobinQ), while other measures of performance are not included.

4) Corporate Governance in the Financial Sector Banks and the financial industry provide an extreme illustration of the distortions created by financialized corporate governance and the shortcomings of laws and regulations.

5) Latest data for the years 2019 and 2020 were not collected due to COVID-19 it's after effects which might have an impact on the performance of all industries including banks.

6) CSR activities are perceived differently by consumers in different cultures, repeating this type of research in other developing countries may generate different results.

7) Non-financial impacts of CSR (effect on brand image and trust of customers, which ultimately achieves customer loyalty) were not included in the study, which was emphasized by the Chun \& Bang (2016) and argued that maximum research has been done on scenario of economic performance and insisted to include non-financial outcomes of CSR.

8) Data availability in developing economies is still difficult, therefore, more effort is required to establish a large database on governance and CSR data.

\subsection{Future Directions}

1) The concept of CG is appropriate to explain the CSR performance of a firm, because it is not well explained in literature especially in the context of emerging economies. There is a gap for conceptual and empirical work that could be completed in future.

2) Further researchers can use the longitudinal data set to examine the lagged effect of CG and leverage on CSR activities and social and financial performance.

3) This study is among the first to examine this issue on a data set of Thailand Banks. Furthermore, only internal CG variables are examined on CSR perfor- 
mance; there is still the gap for future studies to take into account the external CG factors that could affect the bank's performance.

4) The support of stakeholder theory and agency theory in defining the relationship of CG with financial and CSR performance could be studied in future. And their reciprocal relation can also be explored in future among emerging markets.

5) Only published data is used to measure CSR, there is a gap to examine actual CSR activities.

6) Corporate studies can be extended beyond financial, operational and marker performance. Other performance factors could also be considered.

7) There is a chance for academic researchers to plan strategic CSR to clarify its boundaries to identify and solve difficulties incurred in practice of CSR, Lantos \& Easton (2001).

8) You can study level of investment required in CSR for achieving optimal performance by companies so that demand of different stakeholders can be met, Mc Williams \& Siegel (2018).

9) Most of the researches are done on financial and operating performances of firms, there is a gap to study the impact of corporate governance on non-financial indicators such as customer trust, brand image and loyalty (Chun \& Bang, 2016).

10) Many studies have been done on overall performances of companies of one specific sector companies listed in a country. The research should be done specifically on different industrial sectors to see whether different industries of a country have consistent results or have variation. Type of Industry can be considered as the moderator in future studies.

\section{Conflicts of Interest}

The authors declare no conflicts of interest regarding the publication of this paper.

\section{References}

Abdallah, B., \& Hussein, S. (2014). The Effect of Financial Structure, Financial Leverage and Profitability on Value of Shares of Industrial Companies Applied Study on a Sample of Saudi Industrial Companies. Delhi Business Review, 15, 9-25.

https://doi.org/10.51768/dbr.v15i2.152201412

Ahmad, N., Salman, A., \& Shamsi, A. F. (2015). Impact of Financial Leverage on Firms Profitability: An Investigation from Cement Sector of Pakistan. Research Journal of Finance and Accounting, 6, 75-81.

Bannier, C. E., Bofinger, Y., \& Rock, B. (2021). Corporate Social Responsibility and Credit Risk. Finance Research Letters, 117, 679-694. https://doi.org/10.1016/j.frl.2021.102052

Bianchi, E., Bruno, J. M., \& Sarabia-Sanchez, F. J. (2019). The Impact of Perceived CSR on Corporate Reputation and Purchase Intention. European Journal of Management and Business Economics, 28, 206-221. https://doi.org/10.1108/EJMBE-12-2017-0068

Black, B. S., Jang, H., \& Kim, W. (2006). Does Corporate Governance Predict Firms' Market Values? Evidence from Korea. Journal of Law, Economics, and Organization, 22, 
366-413. https://doi.org/10.1093/jleo/ewj018

Braga-Alves, M. V., \& Shastri, K. (2011). Corporate Governance, Valuation, and Performance: Evidence from a Voluntary Market Reform in Brazil. Financial Management, 40, 139-157. https://doi.org/10.1111/j.1755-053X.2010.01137.x

Brown, L. D., \& Caylor, M. L. (2009). Corporate Governance and Firm Operating Performance. Review of Quantitative Finance and Accounting, 32, 129-144. https://doi.org/10.1007/s11156-007-0082-3

Buallay, A., Hamdan, A., \& Zureigat, Q. (2017). Corporate Governance and Firm Performance: Evidence from Saudi Arabia. Australasian Accounting, Business and Finance Journal, 11, 78-98. https://doi.org/10.14453/aabfj.v11i1.6

Carroll, A. B. (2016). Carroll's Pyramid of CSR: Taking Another Look. International Journal of Corporate Social Responsibility, 1, 1-8.

https://doi.org/10.1186/s40991-016-0004-6

Chen, Z., Cheung, Y. L., Stouraitis, A., \& Wong, A. W. S. (2005). Ownership Concentration, Firm Performance, and Dividend Policy in Hong Kong. Pacific Basin Finance Journal, 13, 431-449. https://doi.org/10.1016/j.pacfin.2004.12.001

Cheung, Y. L., Connelly, J. T., Limpaphayom, P., \& Zhou, L. (2007). Do Investors Really Value Corporate Governance? Evidence from the Hong Kong Market. Journal of International Financial Management and Accounting, 18, 86-122. https://doi.org/10.1111/j.1467-646X.2007.01009.x

Chi, J. D. (2011). Understanding the Endogeneity between Firm Value and Shareholder Rights. SSRN Electronic Journal, 4, 65-76. https://doi.org/10.2139/ssrn.925910

Chun, K., \& Bang, W. (2016). Effect of CSR on Customer Loyalty: Moderating Effect of Authenticity. International Journal of $U$ - and e-Service, Science and Technology, 9, 135-142. https://doi.org/10.14257/ijunesst.2016.9.5.12

Collier, J., \& Roberts, J. (2016). Introduction: An Ethic for Corporate Governance? Business Ethics Quarterly, 11, 67-71. http://www.jstor.org/stable/3857869 https://doi.org/10.5840/beq20011117

Core, J. E., Guay, W. R., \& Rusticus, T. O. (2005). American Finance Association Does Weak Governance Cause Weak Stock Returns? An Examination of Firm Operating Performance and Investors Expectations. The Journal of Finance, 61, 655-687.

https://www.jstor.org/stable/3699 https://doi.org/10.1111/j.1540-6261.2006.00851.x

El Ghoul, S., Guedhami, O., Kwok, C. C. Y., \& Mishra, D. R. (2011). Does Corporate Social Responsibility Affect the Cost of Capital? Journal of Banking and Finance, 35, 2388-2406. https://doi.org/10.1016/j.jbankfin.2011.02.007

Ertugrul, M., \& Hegde, S. (2009). Corporate Governance Ratings and Firm Performance. Financial Management, 38, 139-160. https://doi.org/10.1111/j.1755-053X.2009.01031.x

Esa, E., \& Ghazali, N. A. M. (2012). Corporate Social Responsibility and Corporate Governance in Malaysian Government-Linked Companies. Corporate Governance (Bingley), 12, 292-305. https://doi.org/10.1108/14720701211234564

Gill, A., \& Obradovich, J. (2012). The Impact of Corporate Governance and Financial Leverage on the Value of American Firms. International Research Journal of Finance and Economics, 91, 46-56.

Gompers, P., Ishii, J., \& Metrick, A. (2003). Corporate Governance and Equity Prices. Quarterly Journal of Economics, 118, 107-155. https://doi.org/10.1162/00335530360535162

González, V. M. (2013). Leverage and Corporate Performance: International Evidence. 
International Review of Economics and Finance, 25, 169-184. https://doi.org/10.1016/j.iref.2012.07.005

Goss, A., \& Roberts, G. S. (2011). The Impact of Corporate Social Responsibility on the Cost of Bank Loans. Journal of Banking and Finance, 35, 1794-1810. https://doi.org/10.1016/j.jbankfin.2010.12.002

Hong, A. H., \& Sullivan, F. R. (2013). Towards an Idea-Centered, Principle-Base Design to as Creation Approach Support Learning Knowledge. Educational Technology Research and Development, 57, 613-627. https://doi.org/10.1007/s11423-009-9122-0

Jang, S. C. (Shawn), \& Tang, C. H. (Hugo) (2009). Simultaneous Impacts of International Diversification and Financial Leverage on Profitability. Journal of Hospitality and Tourism Research, 33, 347-368. https://doi.org/10.1177/1096348009338529

Javed, A. Y., \& Iqbal, R. (2006). Corporate Governance and Firm Performance: Evidence from Karachi Stock Exchange. Pakistan Development Review, 45, 947-964. https://doi.org/10.30541/v45i4IIpp.947-964

Kim, D. S., Yeo, E., \& Zhang, Y. A. (2017). Corporate Governance and Firm Value: The Impact of Chinese Companies' Corporate Social Responsibility. Korean Journal of Policy Studies, 32, 23-61. https://doi.org/10.52372/kjps32202

Klapper, L. F., \& Love, I. (2004). Corporate Governance, Investor Protection, and Performance in Emerging Markets. Journal of Corporate Finance, 10, 703-728. https://doi.org/10.1016/S0929-1199(03)00046-4

Lantos, G. P., \& Easton, N. (2001). The Boundaries of Strategic Corporate Social Responsibility Professor of Business Administration the Boundaries of Strategic Corporate Social Responsibility. Journal of Consumer Marketing, 18, 595-632. https://doi.org/10.1108/07363760110410281

Latapí Agudelo, M. A., Jóhannsdóttir, L., \& Davídsdóttir, B. (2019). A Literature Review of the History and Evolution of Corporate Social Responsibility. International Journal of Corporate Social Responsibility, 4, 1-23. https://doi.org/10.1186/s40991-018-0039-y

Lau, C. M., Lu, Y., \& Liang, Q. (2016). Corporate Social Responsibility in China: A Corporate Governance Approach. Journal of Business Ethics, 136, 73-87. https://doi.org/10.1007/s10551-014-2513-0

Leng, A. C. A. (2004). The Impact of Corporate Governance Practices on Firms' Financial Performance: Evidence from Malaysian Companies. ASEAN Economic Bulletin, 21, 308-318. https://doi.org/10.1355/AE21-3D

Macey, J. R., Miller, G. P., Stanford, S., Review, L., Nov, N., Macey, J. R., \& Miller, G. P. (1995). Corporate Governance and Commercial Banking: A Comparative Examination of Germany, Japan, and the United States. Stanford Law Review, 48, 73-112. https://doi.org/10.2307/1229150

Madden, K., Scaife, W., \& Crissman, K. (2006). How and Why Small to Medium Size Enterprises (SMEs) Engage with Their Communities: An Australian Study. International Journal of Nonprofit and Voluntary Sector Marketing, 11, 49-60. https://doi.org/10.1002/nvsm.40

Margolis, J. D., \& Walsh, J. R. (2011). Misery Loves Rethinking Companies: Social Initiatives. Administrative Science Quarterly, 48, 268-305. https://doi.org/10.2307/3556659

Mc Williams, A., \& Siegel, D. (2018). Corporate Social Responsibility: A Theory of the Firm Perspective. Business Ethics and Strategy, Volumes I and II, 26, 137-147.

Nag, T. (2016). Corporate Governance in South Africa. Corporate Governance, Responsibility and Sustainability: Initiatives in Emerging Economies, 37, 78-90. https://doi.org/10.1057/9781137361851_5 
Orlitzky, M., Schmidt, F. L., \& Rynes, S. L. (2003). 57-orlitzky2003-Social \& Financial Performance-Meta Analysis.pdf. Organization Studies, 24, 403-441. https://doi.org/10.1177/0170840603024003910

Orlitzky, M., Siegel, D. S., \& Waldman, D. A. (2011). Strategic Corporate Social Responsibility and Environmental Sustainability. Business and Society, 50, 6-27. https://doi.org/10.1177/0007650310394323

Ozdagli, A. K., The, S., Studies, F., April, N., \& Ozdagli, A. K. (2017). The Society for Financial Studies Financial Leverage, Corporate Investment, and Stock Returns Published by: Oxford University Press. Sponsor: The Society for Financial Studies. Stable Financial Leverage C, 25, 1033-1069. http://www.jstor.org/stable/41407855 https://doi.org/10.1093/rfs/hhr145

Pang, S., \& Yuan, J. (2019). Research on the Impact of Corporate Social Responsibility Reputation on Financial Performance-Based on Listed Company Data. Open Journal of Social Sciences, 7, 160-169. https://doi.org/10.4236/jss.2019.71014

Pillai, R., \& Al-Malkawi, H. A. N. (2018). On the Relationship between Corporate Governance and Firm Performance: Evidence from GCC Countries. Research in International Business and Finance, 44, 394-410. https://doi.org/10.1016/j.ribaf.2017.07.110

Porter, M. E., \& Kramer, M. R. (2002). The Competitive Advantage of Corporate Philanthropy. Harvard Business Review, 80, 57.

Ramzan, M., Amin, M., \& Abbas, M. (2021). How Does Corporate Social Responsibility Affect Financial Performance, Financial Stability, and Financial Inclusion in the Banking Sector? Evidence from Pakistan. Research in International Business and Finance, 55, Article ID: 101314. https://doi.org/10.1016/j.ribaf.2020.101314

Setiawan, D., \& Phua, L. K. (2013). Corporate Governance and Dividend Policy in Indonesia. Business Strategy Series, 14, 135-143. https://doi.org/10.1108/BSS-01-2013-0003

Shan, Y. G., \& Round, D. K. (2012). China’s Corporate Governance: Emerging Issues and Problems. Modern Asian Studies, 46, 1316-1344.

https://doi.org/10.1017/S0026749X1200008X

Sharfman, M. P., \& Fernando, C. S. (2008). Environmental Risk Management and the Cost of Capital. Strategic Management Journal, 29, 569-592. https://doi.org/10.1002/smj.678

Singapurwoko, A., \& El-Wahid, M. S. M. (2011). The Impact of Financial Leverage to Profitability Study of Non-Financial Companies Listed in Indonesia Stock Exchange. European Journal of Economics, Finance and Administrative Sciences, 32, 136-148.

Udayasankar, K (2008). Corporate Social Responsibility and Firm Size. Journal of Business Ethics, 83, 167-175. https://doi.org/10.1007/s10551-007-9609-8

Ullah, Z., Ahmad, N., Nazim, Z., \& Ramzan, M. (2020). Impact of Csr on Corporate Reputation, Customer Loyalty and Organizational Performance. Governance and Management Review (GMR), 5, 195-210.

Upadhyay, A., \& Öztekin, Ö. (2020). What Matters More in Board Independence? Form or Substance? SSRN Electronic Journal, 274, 185. https://doi.org/10.2139/ssrn.3678355

Vogler, D., \& Eisenegger, M. (2020). CSR Communication, Corporate Reputation, and the Role of the News Media as an Agenda-Setter in the Digital Age. Business and Society, 60, 1957-1986. https://doi.org/10.1177/0007650320928969

Yadav, R. S., Dash, S. S., Chakraborty, S., \& Kumar, M. (2018). Perceived CSR and Corporate Reputation: The Mediating Role of Employee Trust. Vikalpa, 43, 139-151.

https://doi.org/10.1177/0256090918794823 
Yoon, E., \& Jang, S. C. (2005). The Effect of Financial Leverage on Profitability and Risk of Restaurant Firms. Journal of Hospitality Financial Management, 13, 35-47. https://doi.org/10.1080/10913211.2005.10653798

Zhou, M., Li, K., \& Chen, Z. (2021). Corporate Governance Quality and Financial Leverage: Evidence from China. International Review of Financial Analysis, 73, Article ID: 101652. https://doi.org/10.1016/j.irfa.2020.101652

\section{List of Abbreviations:}

CG: $\quad$ Corporate Governance

CSR: $\quad$ Corporate Social Responsibility

LEVRG: Leverage

ROA: Return on Assets

OP: Operating Profit

CDLTY: $\quad$ CEO Duality

BS: $\quad$ Board Size

AQ: $\quad$ Audit Quality

TMSH: $\quad$ Percentage of two major Shareholders

LISH: $\quad$ Percentage of Large Institutions

INSH: $\quad$ Percentage of Insiders

IND: $\quad$ Percentage of Independent Directors

SEM: $\quad$ Structured Equation Modelling

FEM: $\quad$ Fixed Effect Model

REM: $\quad$ Random Effect Model

FP: $\quad$ Financial Performance

TSLS: $\quad$ Two Stage Least Square

OLS: $\quad$ Ordinary Least Square 